Supporting Information

\title{
Structure-guided design and in-cell target profiling of a cell-active target engagement probe for PARP inhibitors
}

Ryan T. Howard, ${ }^{1}$ Paul Hemsley, ${ }^{2}$ Philip Petteruti, ${ }^{2}$ Charlie N. Saunders, ${ }^{1}$ Javier A. Molina Bermejo, ${ }^{1}$ James S. Scott, ${ }^{2}$ Jeffrey W. Johannes, ${ }^{3}$ Edward W. Tate ${ }^{1,{ }^{*}}$

${ }^{1}$ Department of Chemistry, Molecular Sciences Research Hub, Imperial College London, London W12 0BZ, U.K.

2 Oncology R\&D, AstraZeneca, Cambridge CB4 OWG, U.K.

${ }^{3}$ Oncology, R\&D, AstraZeneca, Boston, Waltham, Massachusetts, 02451, United States. 


\section{Table of Contents}

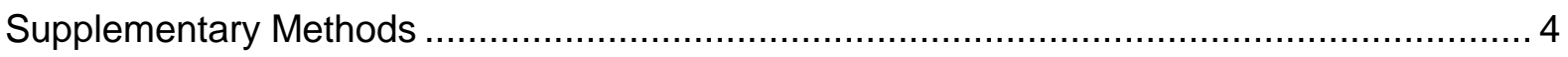

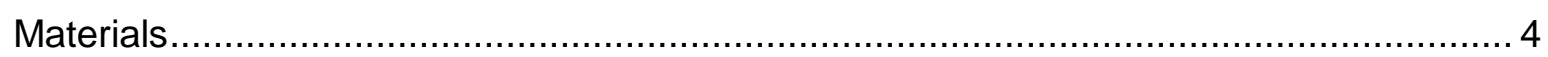

Tert-butyl 4-(3-cyanopyridin-2-yl)piperazine-1-carboxylate (5) ...................................... 4

Tert-butyl 4-(5-bromo-3-cyanopyridin-2-yl)piperazine-1-carboxylate (6) .......................... 4

Tert-butyl 4-(5-amino-3-cyanopyridin-2-yl)piperazine-1-carboxylate (7) .......................... 5

Tert-butyl 4-(5-(3-(3-(but-3-yn-1-yl)-3H-diazirin-3-yl)propanamido)-3-cyanopyridin-2-

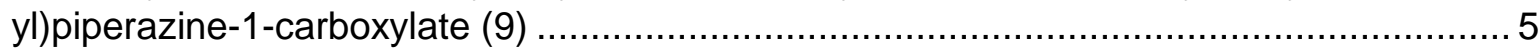

3-(3-(But-3-yn-1-yl)-3H-diazirin-3-yl)-N-(5-cyano-6-(piperazin-1-yl)pyridin-3-

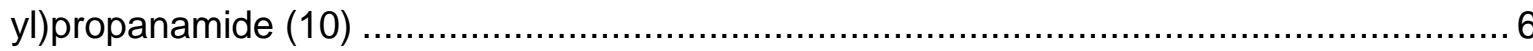

3-(3-(But-3-yn-1-yl)-3H-diazirin-3-yl)-N-(5-cyano-6-(4-(3-((4-oxo-3,4-dihydrophthalazin-1-

yl)methyl)benzoyl)piperazin-1-yl)pyridin-3-yl)propanamide (PARPYnD 3) ...................... 6

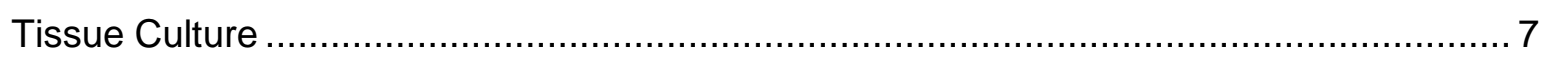

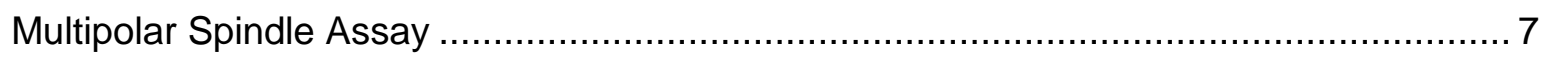

In vitro PARP fluorescence anisotropy binding assays ............................................. 7

Dilution of various PARP proteins and fluorescence anisotropy probe .......................... 7

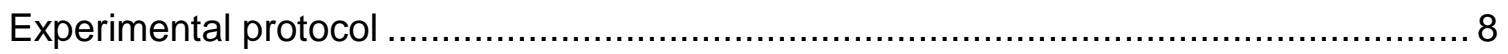

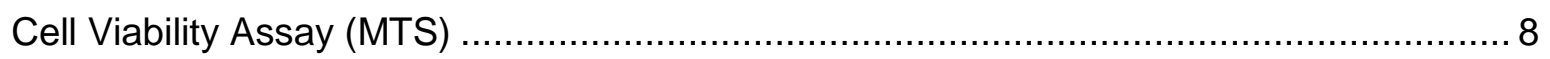

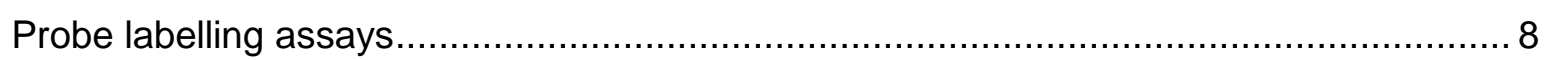



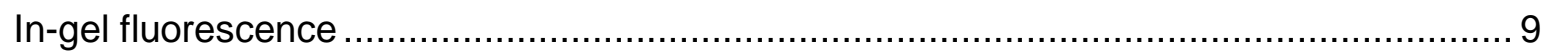

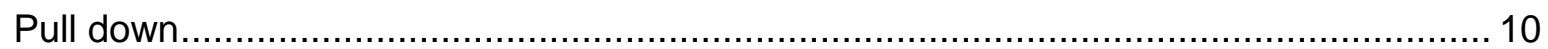

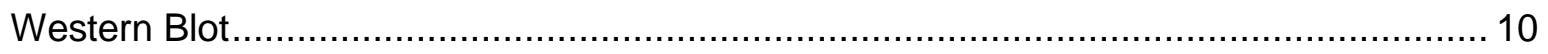

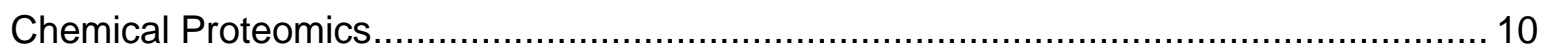

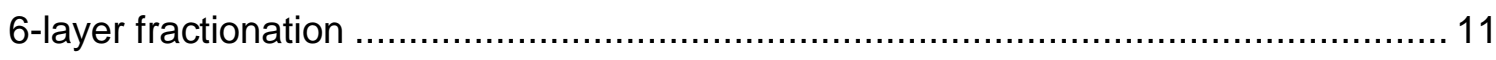

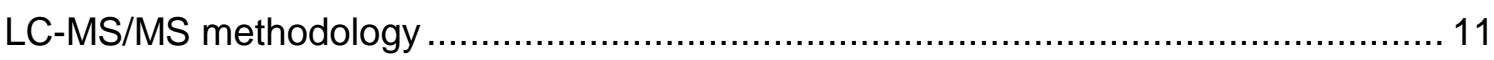

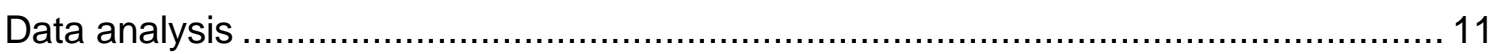

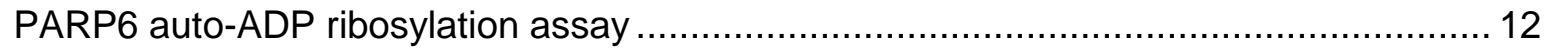

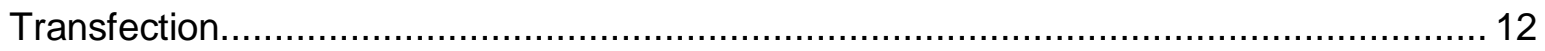

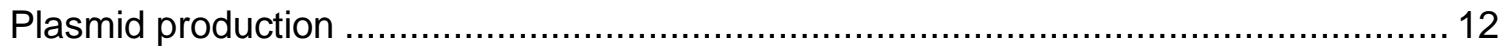

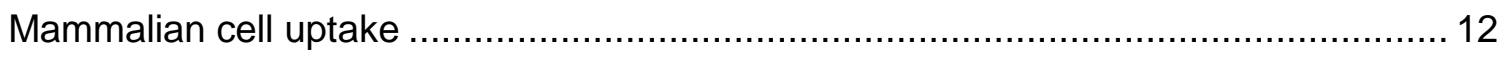

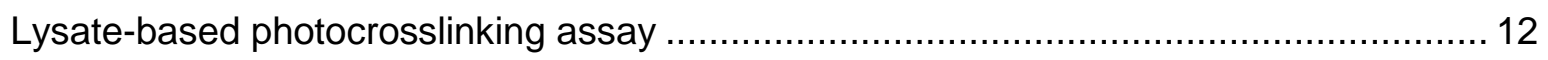

Variation with Prescission ${ }^{\mathrm{TM}}$ Protease .................................................................. 13

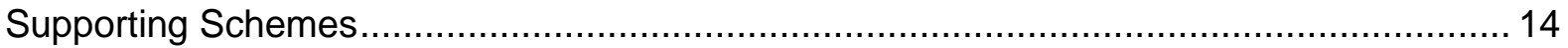

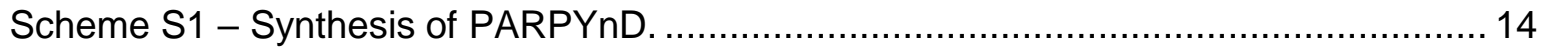

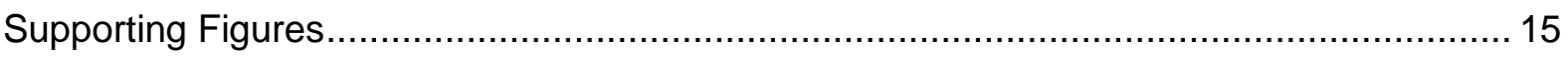

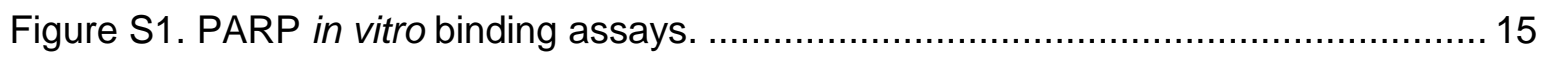

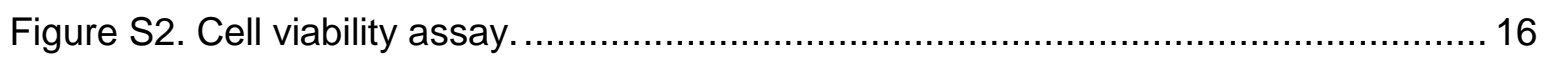


Figure S3. Structure of the clickable capture reagents.......................................... 17



Figure S5. Supplementary volcano and profile plots for PARPYnD. ............................. 19

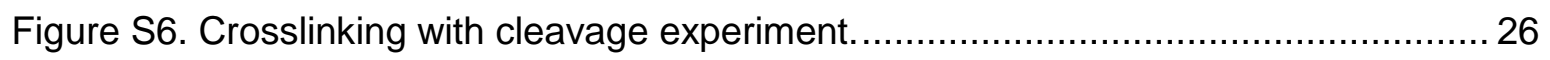

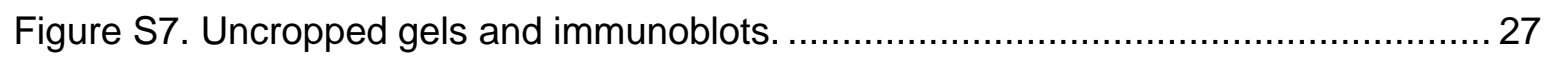

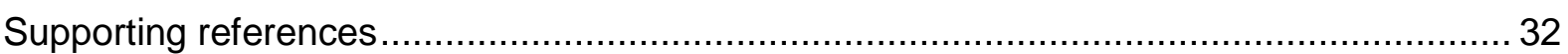

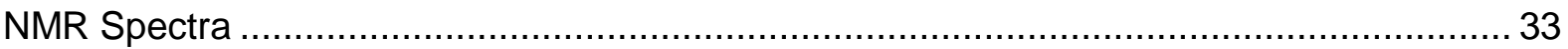




\section{Supplementary Methods}

\section{Materials}

Chemicals were purchased from Sigma-Aldrich, Fluorochem, Acros Organics, TCl, Alfa Aesar or Fisher Scientific and used without further purification. AzTB and AzRB were synthesized in-house as previously reported. ${ }^{1}$ The minimal clickable photocrosslinkable group 5 was synthesized as previously reported. ${ }^{2}$ Phthalazinone core 8, AZ9482 and AZ0108 were provided by AstraZeneca. Olaparib was purchased from VWR International. NeutrAvidin agarose resin and PreScission ${ }^{\mathrm{TM}}$ Protease were purchased from Thermo Fisher Scientific. Streptavidin magnetic beads were purchased from New England BioLabs. Recombinant GSTPARP6 protein and pcDNA3.1 $1^{\mathrm{TM}}$ mammalian expression vector containing FLAG-PARP6 were provided by AstraZeneca. 6-biotin-17-NAD+ was purchased from Bio-Techne Ltd.

Antibodies: anti-PARP1 (SantaCruz, sc-8007), anti-PARP6 (Sigma, HPA026991), antiHDLBP (Abcam ab109324), anti-GAPDH (Abcam, ab9485), anti-HSP90 (SantaCruz, sc69703), FLAG-HRP [M2] (Sigma, A8592), NeutrAvidin-HRP (Invitrogen, A2664), anti-mouseHRP (Advansta, R-05071-500), anti-rabbit-HRP (Advansta, R-05072-500).

Tert-butyl 4-(3-cyanopyridin-2-yl)piperazine-1-carboxylate (5)<smiles>CC(C)(C)OC(=O)N1CCN(c2ncccc2C#N)CC1</smiles>

2

2-(Piperazin-1-yl)nicotinonitrile $1(4.00 \mathrm{~g}, 21.3 \mathrm{mmol})$ and di-tert-butyl dicarbonate $(4.78 \mathrm{~g}$, $21.9 \mathrm{mmol})$ were dissolved in $\mathrm{CH}_{2} \mathrm{Cl}_{2}(60 \mathrm{~mL})$ and cooled to $0{ }^{\circ} \mathrm{C}$. $\mathrm{Et}_{3} \mathrm{~N}(5.60 \mathrm{~mL}, 40.8 \mathrm{mmol})$ was added drop-wise and the solution was stirred for $4 \mathrm{~h}$ at rt. The resulting reaction mixture was quenched with $\mathrm{H}_{2} \mathrm{O}(60 \mathrm{~mL})$ and extracted with $\mathrm{CH}_{2} \mathrm{Cl}_{2}(3 \times 60 \mathrm{~mL})$. The combined organic extracts were washed with $\mathrm{H}_{2} \mathrm{O}(30 \mathrm{~mL})$ and sat. aq. $\mathrm{NaCl}(30 \mathrm{~mL})$, dried over $\mathrm{MgSO}_{4}$ and concentrated in vacuo. The crude product was purified by flash column chromatography $(1: 1$ EtOAc: $n$-hexane) to afford 2 as a white crystalline solid $(2.70 \mathrm{~g}, 9.38 \mathrm{mmol}, 44 \%)$. HRMS $\left(E S I^{+}\right)$found $[\mathrm{M}+\mathrm{H}]^{+}$289.1661, $\mathrm{C}_{15} \mathrm{H}_{21} \mathrm{~N}_{4} \mathrm{O}_{2}{ }^{+}$requires $289.1665 ;{ }^{1} \mathrm{H}$ NMR $(400 \mathrm{MHz}$, Chloroform- $d$ ) $\delta$ ppm 8.35 (dd, $J=4.9,2.0 \mathrm{~Hz}, 1 \mathrm{H}), 7.79$ (dd, $J=7.6,2.1 \mathrm{~Hz}, 1 \mathrm{H}), 6.79$ (dd, $J$ = 7.5, 4.7 Hz, 1H), $3.69-3.65(\mathrm{~m}, 4 \mathrm{H}), 3.61-3.57(\mathrm{~m}, 4 \mathrm{H}), 1.48(\mathrm{~s}, 9 \mathrm{H})$.

\section{Tert-butyl 4-(5-bromo-3-cyanopyridin-2-yl)piperazine-1-carboxylate (6)}<smiles>N#Cc1cc(Br)cnc1N1CCN(C(=O)OCc2ccccc2)CC1</smiles>

3

Tert-butyl 4-(3-cyanopyridin-2-yl)piperazine-1-carboxylate $2 \quad(2.70 \mathrm{~g}, 9.38 \mathrm{mmol})$ was dissolved in DMF $(10 \mathrm{~mL})$ and the solution cooled to $0{ }^{\circ} \mathrm{C}$. $\mathrm{N}$-bromosuccinimide $(2.01 \mathrm{~g}$, $11.3 \mathrm{mmol}$ ) was added and the reaction stirred at $\mathrm{rt}$ for $3 \mathrm{~h}$. The reaction was quenched with $\mathrm{H}_{2} \mathrm{O}(5 \mathrm{~mL})$ and concentrated in vacuo. The crude residue was dissolved in EtOAc $(30 \mathrm{~mL})$ and sat. aq. $\mathrm{NaHCO}_{3}(15 \mathrm{~mL})$ and aq. $\mathrm{LiCl}(5 \%(\mathrm{w} / \mathrm{v}), 15 \mathrm{~mL})$ were added. The mixture was extracted with EtOAc $(3 \times 30 \mathrm{~mL})$ and the combined organic layers were washed successively with sat. aq. $\mathrm{NaHCO}_{3}(15 \mathrm{~mL})$, aq. $\mathrm{LiCl}(5 \%(\mathrm{w} / \mathrm{v}), 15 \mathrm{~mL})$ and sat. aq. $\mathrm{NaCl}(30 \mathrm{~mL})$. The 
organics were dried over $\mathrm{Na}_{2} \mathrm{SO}_{4}$ and concentrated in vacuo to yield 3 as a pale yellow solid $(3.18 \mathrm{~g}, 8.66 \mathrm{mmol}, 93 \%)$ without further purification. HRMS $\left(\mathrm{ESI}^{+}\right)$found $[\mathrm{M}+\mathrm{H}]^{+} 367.0772$, $\mathrm{C}_{15} \mathrm{H}_{20} \mathrm{~N}_{4} \mathrm{O}_{2}{ }^{79} \mathrm{Br}$ requires 367.0770; ${ }^{1} \mathrm{H}$ NMR $(400 \mathrm{MHz}$, Chloroform- $d$ ) $\delta \mathrm{ppm} 8.34(\mathrm{~d}, \mathrm{~J}=$ $2.6 \mathrm{~Hz}, 1 \mathrm{H}), 7.84(\mathrm{~d}, J=2.5 \mathrm{~Hz}, 1 \mathrm{H}), 3.70-3.64(\mathrm{~m}, 4 \mathrm{H}), 3.59-3.54(\mathrm{~m}, 4 \mathrm{H}), 1.47(\mathrm{~s}, 9 \mathrm{H})$.

Tert-butyl 4-(5-amino-3-cyanopyridin-2-yl)piperazine-1-carboxylate (7)<smiles>CC(C)(C)N1CCN(c2ncc(N)cc2C#N)CC1</smiles>

4

Tert-butyl 4-(5-bromo-3-cyanopyridin-2-yl)piperazine-1-carboxylate $3(1.00 \mathrm{~g}, 2.72 \mathrm{mmol})$, Cul (103 mg, $0.542 \mathrm{mmol}$ ), L-proline (563 mg, $4.08 \mathrm{mmol}$ ), $\mathrm{K}_{2} \mathrm{CO}_{3}(563 \mathrm{mg}, 4.08 \mathrm{mmol}$ ) and a stirrer bar were sealed inside a microwave vial which was flushed with Ar. DMSO $(2.5 \mathrm{~mL})$ was added and stirred at it for $5 \mathrm{~min}$. $\mathrm{NH}_{4} \mathrm{OH}(30 \%(\mathrm{w} / \mathrm{w}), 0.520 \mathrm{~mL}, 4.08 \mathrm{mmol})$ was added and the reaction mixture stirred at $90^{\circ} \mathrm{C}$ for $12 \mathrm{~h}$. After cooling, the reaction was quenched with $\mathrm{H}_{2} \mathrm{O}(50 \mathrm{~mL})$ and extracted with $\mathrm{Et}_{2} \mathrm{O}(3 \times 50 \mathrm{~mL})$. The combined organic layers were washed with sat. aq. $\mathrm{NaCl}(50 \mathrm{~mL})$, dried over $\mathrm{MgSO}_{4}$, filtered and concentrated in vacuo. The crude product was purified by flash column chromatography $\left(1: 49 \mathrm{MeOH}: \mathrm{CH}_{2} \mathrm{Cl}_{2}\right)$ to yield 4 as a yellow crystalline solid (426 mg, $1.41 \mathrm{mmol}, 52 \%)$. HRMS $\left(\mathrm{ESI}^{+}\right)$found $[\mathrm{M}+\mathrm{H}]^{+} 304.1767$, $\mathrm{C}_{15} \mathrm{H}_{22} \mathrm{~N}_{5} \mathrm{O}_{2}{ }^{+}$requires 304.1774; ${ }^{1} \mathrm{H}$ NMR $\left(400 \mathrm{MHz}\right.$, Methanol- $\left.d_{4}\right) \delta \mathrm{ppm} 7.93(\mathrm{~d}, J=2.7 \mathrm{~Hz}$, $1 \mathrm{H}), 7.30(\mathrm{~d}, J=2.8 \mathrm{~Hz}, 1 \mathrm{H}), 3.60-3.52(\mathrm{~m}, 4 \mathrm{H}), 3.26-3.18(\mathrm{~m}, 4 \mathrm{H}), 1.48(\mathrm{~s}, 9 \mathrm{H})$.

Tert-butyl 4-(5-(3-(3-(but-3-yn-1-yl)-3H-diazirin-3-yl)propanamido)-3-cyanopyridin-2yl)piperazine-1-carboxylate (9)

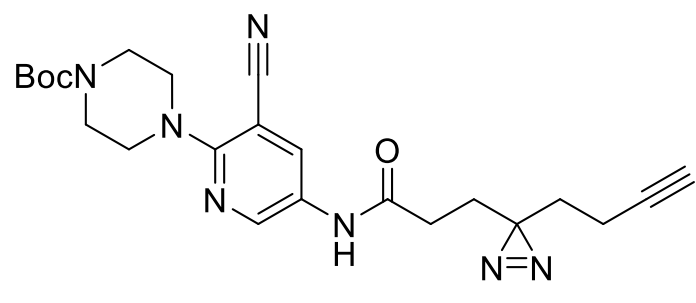

6

DIPEA $\quad(110 \mu \mathrm{L}, \quad 0.631 \mathrm{mmol}), \quad$ tert-butyl $\quad$ 4-(5-amino-3-cyanopyridin-2-yl)piperazine-1carboxylate 4 (64 mg, $0.211 \mathrm{mmol}$ ), and 3-(3-(but-3-yn-1-yl)-3H-diazirin-3-yl)propanoic acid 5 (35 mg, $0.211 \mathrm{mmol}$ ) were dissolved in DMF (2 mL). Propylphosphonic acid cyclic anhydride $(50 \%(\mathrm{v} / \mathrm{v})$ in EtOAc, $249 \mu \mathrm{L}, 4.19 \mathrm{mmol})$ was added and the reaction stirred at $\mathrm{rt}$ for $1 \mathrm{~h}$. The reaction mixture was diluted with sat. aq. $\mathrm{NaHCO}_{3}(5 \mathrm{~mL})$ and extracted with EtOAc $(3 \times 5 \mathrm{~mL})$. The combined organic layers were washed with sat. aq. $\mathrm{NaHCO}_{3}(5 \mathrm{~mL})$ and aq. $\mathrm{LiCl}(5 \%$ $(\mathrm{w} / \mathrm{v}), 2 \times 5 \mathrm{~mL})$, dried over $\mathrm{MgSO}_{4}$, filtered and concentrated in vacuo. The crude residue was purified by flash column chromatography $\left(1: 7\right.$ acetone: $\left.\mathrm{CH}_{2} \mathrm{Cl}_{2}\right)$ to yield 6 as a brown oil (219 mg, $0.448 \mathrm{mmol}, 75 \%)$. HRMS $\left(\mathrm{ESI}{ }^{+}\right.$) found $[\mathrm{M}+\mathrm{H}]^{+} 452.2419, \mathrm{C}_{23} \mathrm{H}_{30} \mathrm{~N}_{7} \mathrm{O}_{3}{ }^{+}$requires 452.2410; ' ${ }^{\mathrm{H}} \mathrm{NMR}(400 \mathrm{MHz}$, Chloroform- $d$ ) $\delta \mathrm{ppm} 8.32(\mathrm{~d}, J=2.7 \mathrm{~Hz}, 1 \mathrm{H}), 8.23(\mathrm{~d}, J=$ $2.8 \mathrm{~Hz}, 1 \mathrm{H}), 7.85(\mathrm{~s}, 1 \mathrm{H}), 3.56(\mathrm{~s}, 8 \mathrm{H}), 2.11(\mathrm{t}, J=7.4 \mathrm{~Hz}, 2 \mathrm{H}), 2.05-1.97(\mathrm{~m}, 3 \mathrm{H}), 1.93(\mathrm{t}, J$ $=7.4 \mathrm{~Hz}, 2 \mathrm{H}), 1.66(\mathrm{t}, J=7.3 \mathrm{~Hz}, 2 \mathrm{H}), 1.47(\mathrm{~s}, 9 \mathrm{H})$. 
<smiles>C#CCCC1(CCC(=O)Nc2cnc(N3CCNCC3)c(C#N)c2)N=N1</smiles>

Tert-butyl 4-(5-(3-(3-(but-3-yn-1-yl)-3H-diazirin-3-yl)propanamido)-3-cyanopyridin-2yl)piperazine-1-carboxylate $6(37 \mathrm{mg}, 0.0819 \mathrm{mmol})$ was dissolved in $\mathrm{CH}_{2} \mathrm{Cl}_{2}(3 \mathrm{~mL}) . \mathrm{N}$ methylmorpholine $(0.460 \mathrm{~mL}, 0.419 \mathrm{mmol})$ and trimethylsilyl iodide $(0.330 \mathrm{~mL}, 0.231 \mathrm{mmol})$ were added and stirred under $\mathrm{Ar}$ at $\mathrm{rt}$ for $24 \mathrm{~h}$. The reaction mixture was quenched with sat. aq. $\mathrm{NaHCO}_{3}(5 \mathrm{~mL})$ and the aqueous layer extracted with $\mathrm{CH}_{2} \mathrm{Cl}_{2}(3 \times 5 \mathrm{~mL})$. The combined organic layers were dried over $\mathrm{Na}_{2} \mathrm{SO}_{4}$, filtered and concentrated in vacuo to yield 7 as a crude brown oil (28 mg, $0.0798 \mathrm{mmol}, 96 \%$ ) that was taken forward without further purification. HRMS $\left(\mathrm{ESI}^{+}\right)$found $[\mathrm{M}+\mathrm{H}]^{+} 352.1893, \mathrm{C}_{18} \mathrm{H}_{22} \mathrm{~N}_{7} \mathrm{O}^{+}$requires $352.1886 ;{ }^{1} \mathrm{H}$ NMR $(400 \mathrm{MHz}$, Methanol- $\left.d_{4}\right) \delta$ ppm $8.47(\mathrm{~d}, J=2.4 \mathrm{~Hz}, 1 \mathrm{H}), 8.25(\mathrm{~d}, J=2.7 \mathrm{~Hz}, 1 \mathrm{H}), 3.72-3.65(\mathrm{~m}, 4 \mathrm{H})$, $3.05-3.00(\mathrm{~m}, 4 \mathrm{H}), 2.27(\mathrm{t}, J=2.9 \mathrm{~Hz}, 1 \mathrm{H}), 2.21(\mathrm{t}, J=7.6 \mathrm{~Hz}, 2 \mathrm{H}), 2.04(\mathrm{td}, J=7.5,2.7 \mathrm{~Hz}$, $2 \mathrm{H}), 1.84(\mathrm{t}, J=7.6 \mathrm{~Hz}, 2 \mathrm{H}), 1.64(\mathrm{t}, J=7.4 \mathrm{~Hz}, 2 \mathrm{H})$.

\section{3-(3-(But-3-yn-1-yl)-3H-diazirin-3-yl)-N-(5-cyano-6-(4-(3-((4-oxo-3,4-dihydrophthalazin- 1-yl)methyl)benzoyl)piperazin-1-yl)pyridin-3-yl)propanamide (PARPYnD 3)}<smiles>C#CCCC1(CCC(=O)Nc2cnc(N3CCN(C(=O)c4cccc(Cc5n[nH]c(=O)c6ccccc56)c4)CC3)c(C#N)c2)N=N1</smiles>

PARPYnD

DIPEA (51 $\mu \mathrm{L}, 0.293 \mathrm{mmol}), 3-(3-($ but-3-yn-1-yl)-3H-diazirin-3-yl)- $N$-(5-cyano-6-(piperazin-1yl)pyridin-3-yl)propanamide 7 (28 mg, $0.0798 \mathrm{mmol})$, and 3-((4-oxo-3,4-dihydrophthalazin-1yl)methyl)benzoic acid 8 (22 $\mathrm{mg}, 0.0798 \mathrm{mmol})$ were dissolved in DMF $(500 \mu \mathrm{L})$. Propylphosphonic acid cyclic anhydride (50\% (v/v) in EtOAc, $95 \mu \mathrm{L}, 0.293 \mathrm{mmol})$ was added and the reaction stirred at $\mathrm{rt}$ for $30 \mathrm{~min}$. The reaction mixture was diluted with sat. aq. $\mathrm{NaHCO}_{3}$ $(5 \mathrm{~mL})$ and extracted with EtOAc $(3 \times 5 \mathrm{~mL})$. The combined organic layers were washed with sat. aq. $\mathrm{NaHCO}_{3}(5 \mathrm{~mL})$ and aq. $\mathrm{LiCl}(5 \%(\mathrm{w} / \mathrm{v}), 2 \times 5 \mathrm{~mL})$, dried over $\mathrm{MgSO}_{4}$, filtered and concentrated in vacuo. The crude residue was purified by preparative reverse phase LC-MS $\left(50-98 \% \mathrm{MeCN}\right.$ in $\left.\mathrm{H}_{2} \mathrm{O}\left(0.1 \% \mathrm{HCO}_{2} \mathrm{H}\right)\right)$ to yield PARPYnD as a white solid $(12 \mathrm{mg}$, 0.0195 mmol, 24\%). MS: ES ${ }^{+}$614.47; HRMS (ESI) found [M-H] $612.2465, \mathrm{C}_{34} \mathrm{H}_{30} \mathrm{~N}_{9} \mathrm{O}_{3}{ }^{-}$ requires 612.2472; ${ }^{1} \mathrm{H}$ NMR $\left(400 \mathrm{MHz}, \mathrm{DMSO}-\mathrm{d}_{6}\right) \delta \mathrm{ppm} 12.60(\mathrm{~s}, 1 \mathrm{H}), 10.33(\mathrm{~s}, 1 \mathrm{H}), 8.52(\mathrm{~d}$, $\mathrm{J}=2.7 \mathrm{~Hz}, 1 \mathrm{H}), 8.29(\mathrm{~d}, \mathrm{~J}=2.7 \mathrm{~Hz}, 1 \mathrm{H}), 8.26(\mathrm{~d}, \mathrm{~J}=7.7 \mathrm{~Hz}, 1 \mathrm{H}), 7.97(\mathrm{~d}, \mathrm{~J}=7.9 \mathrm{~Hz}, 1 \mathrm{H})$, $7.89(\mathrm{t}, \mathrm{J}=7.5 \mathrm{~Hz}, 1 \mathrm{H}), 7.82(\mathrm{t}, \mathrm{J}=7.5 \mathrm{~Hz}, 1 \mathrm{H}), 7.40(\mathrm{q}, \mathrm{J}=7.0 \mathrm{~Hz}, 3 \mathrm{H}), 7.28(\mathrm{~d}, \mathrm{~J}=7.1 \mathrm{~Hz}$, 
1H), $4.36(\mathrm{~s}, 2 \mathrm{H}), 3.80-3.66(\mathrm{~m}, 2 \mathrm{H}), 3.60-3.42(\mathrm{~m}, 6 \mathrm{H}), 2.84(\mathrm{t}, \mathrm{J}=2.7 \mathrm{~Hz}, 1 \mathrm{H}), 2.16(\mathrm{t}, \mathrm{J}$ $=7.6 \mathrm{~Hz}, 2 \mathrm{H}), 2.01(\mathrm{td}, \mathrm{J}=7.6,2.9 \mathrm{~Hz}, 2 \mathrm{H}), 1.75(\mathrm{t}, \mathrm{J}=7.5 \mathrm{~Hz}, 2 \mathrm{H}), 1.60(\mathrm{t}, \mathrm{J}=7.4 \mathrm{~Hz}, 2 \mathrm{H})$.

\section{Tissue Culture}

All cell culturing was carried out in a sterile tissue culture cabinet sprayed with $70 \%(\mathrm{v} / \mathrm{v}) \mathrm{EtOH}$ before and after use. All cell lines were cultured at $37^{\circ} \mathrm{C}$ in a $5 \% \mathrm{CO}_{2}$ incubator. MDA-MB468 cells were cultured in Dubecco's Modified Eagle Medium - low glucose (DMEM) supplemented with $10 \%$ (v/v) Fetal Bovine Serum (FBS). Cell harvesting was achieved by washing with Dubecco's PBS and treatment with $0.25 \%$ (w/v) Trypsin-EDTA. After 5 min incubation at $37^{\circ} \mathrm{C}$, the trypsin was quenched with DMEM to the appropriate volume for passage and aliquoted into the appropriate number of cell culture plates. Mycoplasma tests were carried out monthly. Passage number was limited to 20-25 and stocks of early passages were frozen at $-150{ }^{\circ} \mathrm{C}$ containing $\sim 10^{6}$ cells in $1 \mathrm{~mL}$ FBS containing $10 \%(\mathrm{v} / \mathrm{v})$ DMSO.

\section{Multipolar Spindle Assay}

This was performed as described previously. ${ }^{3}$ Briefly, HeLa cells were plated in 96-well plates at 7,000 cells per well and incubated at $37^{\circ} \mathrm{C}$ overnight. The cells were treated with compounds in a dose-dependent manner from 0 to $11 \mu \mathrm{M}$ for $48 \mathrm{~h}$. The cells were fixed by $4 \%(\mathrm{v} / \mathrm{v})$ formaldehyde at room temperature for $10 \mathrm{~min}$ and followed by ice-cold methanol fixation for another $10 \mathrm{~min}$. After washing with PBS four times, the cells were blocked in blocking buffer for $1 \mathrm{~h}$ at room temperature. The cells were labelled with primary antibodies, 1:2000 dilution of anti-cyclin B antibody (Thermo Fisher) and 1:4000 dilution of anti-pericentrin antibody (Abcam), for $16 \mathrm{~h}$ at $4{ }^{\circ} \mathrm{C}$. After washing with PBS four times, the cells were labelled with secondary antibodies, 1:200 Alexa Fluor 488 anti-rabbit antibody and Alexa Fluor 594 anti-mouse antibody, for $1 \mathrm{~h}$ at room temperature. After washing with PBS twice, the nuclei were stained with 4',6-diamidino-2-phenylindole (DAPI) for $10 \mathrm{~min}$ at room temperature. The cells were washed twice with PBS and then applied to image acquisition by ImageXpress Micro High Content Screening System (Molecular Devices). The data were analyzed by MetaXpress and accessed by AcuityXpress (Molecular Devices). The 16 fields in each well were acquired by ImageXpress Micro. The cyclin B was labelled for scoring the mitotic cells and pericentrin was labelled for scoring the centrosome number in each mitotic cell. Value output was taken as \% mitotic cells with greater than 2 centrosomes.

\section{In vitro PARP fluorescence anisotropy binding assays}

Dilution of various PARP proteins and fluorescence anisotropy probe

Recombinant full length 6 HIS-tagged PARP1 protein was diluted to $6 \mathrm{nM}$ with $50 \mathrm{mM}$ Tris $\mathrm{pH} 8,0.001 \%(\mathrm{v} / \mathrm{v})$ Triton X-100, $10 \mathrm{mM} \mathrm{MgCl}_{2}, 150 \mathrm{mM} \mathrm{NaCl}$ and incubated for four hours with an equivalent volume of $2 \mathrm{nM}$ fluorescent probe diluted with $50 \mathrm{mM}$ Tris $\mathrm{pH} 8,0.001 \%$ $(\mathrm{v} / \mathrm{v})$ Triton $\mathrm{X}-100,10 \mathrm{mM} \mathrm{MgCl}_{2}, 150 \mathrm{mM} \mathrm{NaCl}$. The final DMSO concentration of the probe was kept below $1 \%(\mathrm{v} / \mathrm{v})$.

Recombinant full length PARP2 protein was diluted to $6 \mathrm{nM}$ with $50 \mathrm{mM}$ Tris $\mathrm{pH} 8,0.001 \%$ (v/v) Triton X-100, $10 \mathrm{mM} \mathrm{MgCl}_{2}, 150 \mathrm{mM} \mathrm{NaCl}$ and incubated for four hours with an equivalent volume of $2 \mathrm{nM}$ fluorescent probe diluted with $50 \mathrm{mM}$ Tris $\mathrm{pH} 8,0.001 \%(\mathrm{v} / \mathrm{v})$ Triton $\mathrm{X}-100,10 \mathrm{mM} \mathrm{MgCl}, 150 \mathrm{mM} \mathrm{NaCl}$. The final DMSO concentration of the probe was kept below $1 \%(\mathrm{v} / \mathrm{v})$.

Recombinant PARP5a binding domain was diluted to $160 \mathrm{nM}$ with $50 \mathrm{mM}$ Tris $\mathrm{pH} 8,0.001 \%$ $(\mathrm{v} / \mathrm{v})$ Triton X-100, $10 \mathrm{mM} \mathrm{MgCl} 2,150 \mathrm{mM} \mathrm{NaCl}$ and incubated for four hours with an equivalent volume of $6 \mathrm{nM}$ fluorescent probe diluted with $50 \mathrm{mM}$ Tris $\mathrm{pH} 8,0.001 \%(\mathrm{v} / \mathrm{v})$ Triton $\mathrm{X}-100,10 \mathrm{mM} \mathrm{MgCl} 2,150 \mathrm{mM} \mathrm{NaCl}$. The final DMSO concentration of the probe was kept below $1 \%(v / v)$. 
Recombinant full length GST-tagged PARP6 protein was diluted to $160 \mathrm{nM}$ with $50 \mathrm{mM}$ Tris $\mathrm{pH} 8,0.001 \%(\mathrm{v} / \mathrm{v})$ Triton X-100, $10 \mathrm{mM} \mathrm{MgCl}_{2}, 150 \mathrm{mM} \mathrm{NaCl}$ and incubated for four hours with an equivalent volume of $6 \mathrm{nM}$ fluorescent probe diluted with $50 \mathrm{mM}$ Tris $\mathrm{pH} 8,0.001 \%$ $(\mathrm{v} / \mathrm{v})$ Triton X-100, $10 \mathrm{mM} \mathrm{MgCl}_{2}, 150 \mathrm{mM} \mathrm{NaCl}$. The final DMSO concentration of the probe was kept below $1 \%(\mathrm{v} / \mathrm{v})$.

\section{Experimental protocol}

Fluorescence anisotropy of the probe when bound to the proteins was measured using a BMG Pherastar $\mathrm{FS}^{\odot}$ in the presence of test compounds or solvent control and the effect on anisotropy determined. \% inhibition values for different test compound concentrations were calculated and fitted to a four parameter logistic plot in order to determine the $\mathrm{IC}_{50}$ value.

\section{Cell Viability Assay (MTS)}

MDA-MB-468 cells were seeded $24 \mathrm{~h}$ before treatment in a sterile treated 96 -well plate at a density of 8000 cells per well to a final volume of $50 \mu \mathrm{L}$ in DMEM. PBS $(100 \mu \mathrm{L})$ was added to the outer wells. DMEM $(50 \mu \mathrm{L})$ containing $0.2 \%(\mathrm{v} / \mathrm{v})$ DMSO (positive control, final amount $0.1 \%(\mathrm{v} / \mathrm{v})$ on plate) or puromycin (negative control, $8 \mathrm{mM}$, final concentration $4 \mathrm{mM}$ on plate), or different concentrations of compound in DMSO to be tested (final $0.1 \%(\mathrm{v} / \mathrm{v}) \mathrm{DMSO}$, prepared by serial dilution, dilution factor 3 , starting from $3 \mu \mathrm{M}$, final plate concentration starting from $1.5 \mu \mathrm{M}$ ) were added to the cells in triplicate. $72 \mathrm{~h}$ later, a solution of MTS assay powder (3.28 mM in PBS 1x, Promega) and phenazine methosulfate ( $3 \mathrm{mM}$ in $\mathrm{H}_{2} \mathrm{O}$, SigmaAldrich) was prepared (20:1) and $20 \mu \mathrm{L}$ was added to each well. Absorbance was measured 4 times per well at $490 \mathrm{~nm}$ and the average absorbance taken. The average of the negative control was subtracted from every value and viability was calculated as a percentage relative to the positive control. $\mathrm{EC}_{50}$ values were calculated by fitting data to the $\mathrm{IC}_{50}$ function using GraphPad Prism 5 software.

\section{Probe labelling assays}

Probe incubation was carried out in sterile treated 6-well plates ( $2 \mathrm{~mL}$ working volume) or $10 \mathrm{~cm}$ dishes ( $7 \mathrm{~mL}$ working volume). All compound treatments were performed with a preprepared $1000 \times$ stock of the desired concentration in DMSO and added directly to the relevant plate/well with mixing. Irradiation was performed with an in-house designed and built UV LED box (C. Saunders) with a monochromatic wavelength of $365 \mathrm{~nm}$. Optimal probe incubation times were determined previously through irradiation and lysis at various time points and selection of the earliest saturating time point.

For each experiment, the plates/dishes were pre-seeded with MDA-MB-468 cells and the experiment carried out when cells had achieved $90-100 \%$ confluency. DMEM was replaced and the plates/dishes were incubated at $37^{\circ} \mathrm{C}$ for $15 \mathrm{~min}$. For competition experiments only, the relevant plates/wells were first treated with DMSO vehicle $(0.1 \%(\mathrm{v} / \mathrm{v}))$ or varying concentrations of parent compound in DMSO as indicated and incubated at $37^{\circ} \mathrm{C}$ for $1 \mathrm{~h}$ before treating with probe. For all probe labelling experiments, competition or otherwise, the plates/dishes were treated with either DMSO vehicle $(0.1 \%(\mathrm{v} / \mathrm{v}))$ or varying concentrations of probe as required by the experiment and incubated at $37^{\circ} \mathrm{C}$ for $3 \mathrm{~h}$.

For photocrosslinking, the following was performed 1 plate/3 dishes at a time out of the incubator. Each plate/dish had media replaced and was irradiated with UV light for $30 \mathrm{~s}$ $(365 \mathrm{~nm})$ and placed on ice while irradiation of other samples was performed.

The cells were relieved of media, washed twice with PBS, then lysed with lysis buffer $(70 \mu \mathrm{L}$ (6-well plates), $300 \mu \mathrm{L}$ (10 cm dishes); $1 \%$ (v/v) Triton X-100, 1\% (w/v) sodium dodecyl sulfate (SDS), EDTA-free complete protease inhibitor cocktail (1x, Roche) in PBS) on ice for $10 \mathrm{~min}$. The lysates were scraped and transferred to corresponding Lo-Bind Eppendorfs. Each lysate 
was probe sonicated ( $20 \%$ amplitude, $20 \mathrm{~s}$ ( $2 \mathrm{~s}$ pulse, $3 \mathrm{~s}$ rest)) to shear the nuclear DNA. Protein concentration was determined using the DC Protein Assay (Bio-Rad) in a 96-well plate as per manufacturer's instructions.

\section{Click reaction}

The desired amount of lysed protein from each sample was made up to $0.5-2 \mathrm{mg} \mathrm{mL}^{-1}$ with PBS to a total volume of $\leq 300 \mu \mathrm{L}$. The following "click mixture" was prepared separately, preparing $6 \mu \mathrm{L}$ for every $100 \mu \mathrm{L}$ of lysate:

- Click reagent (AzTB or AzRB, $10 \mathrm{mM}$ in DMSO, 1 vol; final concentration in reaction $0.1 \mathrm{mM})$,

- $\mathrm{CuSO}_{4}\left(50 \mathrm{mM}\right.$ in $\mathrm{H}_{2} \mathrm{O}, 2$ vol; final concentration in reaction $\left.1 \mathrm{mM}\right)$,

- Tris(2-carboxyethyl)phosphine (TCEP, $50 \mathrm{mM}$ in $\mathrm{H}_{2} \mathrm{O}, 2$ vol; final concentration in reaction $1 \mathrm{mM})$,

- Tris(benzyltriazolylmethyl)amine (TBTA, $10 \mathrm{mM}$ in DMSO, 1 vol; final concentration in reaction $0.1 \mathrm{mM})$.

The click mixture was vortexed and incubated at $\mathrm{rt}$ for $2 \mathrm{~min}$ before $6 \mu \mathrm{L}$ of the mixture was added to every $100 \mu \mathrm{L}$ of lysate. The reaction mixtures were shaken at $\mathrm{rt}$ for $1 \mathrm{~h}$ before being quenched with EDTA ( $500 \mathrm{mM}$ in $\mathrm{H}_{2} \mathrm{O}$ ) to a final concentration of $5 \mathrm{mM}$.

A table-top centrifuge was pre-chilled to $4^{\circ} \mathrm{C}$. Proteins were precipitated by adding $\mathrm{H}_{2} \mathrm{O}$ (1 vol), $\mathrm{MeOH}(2 \mathrm{vol})$ and $\mathrm{CHCl}_{3}(0.5 \mathrm{vol})$, vortexing briefly then centrifuging at $17,000 \times \mathrm{g}$ for 5 min. The $\mathrm{CHCl}_{3}$ and $\mathrm{H}_{2} \mathrm{O} / \mathrm{MeOH}$ layers were discarded and the middle layer of protein pellet was retained. The pellet was washed with $\mathrm{MeOH}(300 \mu \mathrm{L})$, sonicated to break up the pellet then stored at $-80^{\circ} \mathrm{C}$ for at least $20 \mathrm{~min}$. The proteins were pelleted by centrifugation at $10,000-17000 \times g$ for $5-10$ min or until a compact pellet was formed. The $\mathrm{MeOH}$ was decanted and the pellet air-dried for $5 \mathrm{~min}$. The pellet was resuspended by completely dissolving in $1 \%(\mathrm{w} / \mathrm{v})$ SDS in PBS (to $5 \mathrm{mg} \mathrm{mL}^{-1}$ protein) before being made up to $1 \mathrm{mg} \mathrm{mL}^{-1}$ protein with PBS.

\section{In-gel fluorescence}

10 - or 15 -well SDS-polyacrylamide gels with a $12 \%$ resolving gel and $4 \%$ stacking gel were used for all gel electrophoresis experiments and were prepared using the following recipe (makes 2 gels):

\begin{tabular}{ccc}
\hline Reagent & Resolving gel (12\%) & Stacking gel (4\%) \\
\hline $\mathrm{H}_{2} \mathrm{O}$ & $3.4 \mathrm{~mL}$ & $3.05 \mathrm{~mL}$ \\
Resolving/Stacking Buffer (National Diagnostics) & $2.5 \mathrm{~mL}$ & $1.25 \mathrm{~mL}$ \\
Protogel 30\% (National Diagnostics) & $4 \mathrm{~mL}$ & $0.65 \mathrm{~mL}$ \\
Ammonium Persulfate (10\% (w/v) in $\left.\mathrm{H}_{2} \mathrm{O}\right)$ & $100 \mu \mathrm{L}$ & $25 \mu \mathrm{L}$ \\
$N, N, N^{\prime}, N^{\prime}$ - tetramethylethylene diamine & $10 \mu \mathrm{L}$ & $5 \mu \mathrm{L}$ \\
\hline
\end{tabular}

All gels were run using a Bio-Rad Mini-PROTEIN® Tetra Cell with a Bio-Rad PowerPac ${ }^{\mathrm{TM}}$ Basic power supply. In general, $15 \mu \mathrm{g}$ of protein was run per well in a volume of $15 \mu \mathrm{L}$.

Samples were prepared by adding $5 \mu \mathrm{L}$ of $4 \times$ loading buffer $(1: 4 \beta$-mercaptoethanol:5x NuPAGE LDS sample buffer) to $15 \mu \mathrm{L}$ of sample and boiling at $95^{\circ} \mathrm{C}$ for $10 \mathrm{~min}$. The samples were briefly centrifuged then $15 \mu \mathrm{L}$ of each sample was added to a well of the gel, with at least one well also containing Precision Plus Protein ${ }^{\mathrm{TM}}$ All Blue Prestained Protein Standard $(2 \mu \mathrm{L}$, Bio-Rad). The gels were run in running buffer (25 mM trizma base, $194 \mathrm{mM}$ glycine, 1\% (w/v) 
SDS) for $10 \mathrm{~min}$ at $85 \mathrm{~V}$ then up to $1 \mathrm{~h}$ at $180 \mathrm{~V}$. The fluorescence on the gel was detected using a Typhoon ${ }^{\text {TM }}$ FLA 9500 biomolecular imager (GE Healthcare Life Sciences) detecting TAMRA fluorescence, and the contrast normalized using Fiji (ImageJ) software. The protein loading was verified by staining with Coomassie Brilliant Blue. Coomassie stained gels were imaged using the digitization method (trans-illumination) on an ImageQuant LAS-4000 Imaging System (Fujifilm) and the contrast normalized in Fiji.

\section{Pull down}

$50 \mu \mathrm{L}$ of Pierce ${ }^{\mathrm{TM}}$ NeutrAvidin ${ }^{\mathrm{TM}}$ Agarose beads (proteomics) or $300 \mu \mathrm{L}$ of streptavidin coated magnetic beads (western blot) were used per $1 \mathrm{mg}$ of total protein per sample to an absolute minimum of $20 \mu \mathrm{L}$ of agarose beads or $15 \mu \mathrm{L}$ magnetic beads. All bead washes were performed by moderate shaking for 1 min then either briefly pelleting by table-top centrifuge then vacuum aspirating the supernatant with fine-end pipette tips (agarose) or by partitioning the beads using a magnet (magnetic). The beads were pre-washed three times with $0.2 \%$ $(\mathrm{w} / \mathrm{v})$ SDS in PBS, then protein samples $\left(1 \mathrm{mg} \mathrm{mL}^{-1}\right)$ were added over the beads and incubated with moderate shaking at $\mathrm{rt}$ for $2 \mathrm{~h}$.

For western blot analysis, the beads were washed three times with $300 \mu \mathrm{L} 0.2 \%(\mathrm{w} / \mathrm{v}) \mathrm{SDS}$ in PBS and captured proteins were released from the beads by boiling in $14 \mu \mathrm{L} 2 \times$ sample loading buffer $\left(95^{\circ} \mathrm{C}, 10 \mathrm{~min}\right)$, briefly centrifuging and the supernatant loaded straight on to an SDS-PAGE gel. For proteomic analysis (agarose beads), the beads were treated as described below.

\section{Western Blot}

SDS-PAGE gels intended for western blot were prepared and run as outlined above. Proteins were wet transferred to nitrocellulose membrane (GE healthcare) in transfer buffer $(120 \mathrm{mM}$ tris, $40 \mathrm{mM}$ glycine, $20 \%(\mathrm{v} / \mathrm{v}) \mathrm{MeOH})$ at $100 \mathrm{~V}$ for $1 \mathrm{~h}$. Successful transfer was confirmed by staining with Ponceau S. Membranes were blocked $(5 \%(\mathrm{w} / \mathrm{v})$ non-fat dried skimmed milk powder in TBS-T $(1 \times$ tris-buffered saline, $0.1 \%(\mathrm{v} / \mathrm{v})$ Tween-20) or $3 \%(\mathrm{w} / \mathrm{v})$ bovine serum albumin (BSA) in TBS-T) for $1 \mathrm{~h}$ at rt. Staining with primary antibody was performed either in milk TBS-T or $0.3 \%(\mathrm{w} / \mathrm{v})$ BSA in TBS-T for $1 \mathrm{~h}$ at it or overnight at $4{ }^{\circ} \mathrm{C}$. The blot was washed with TBS-T ( $3 \times 5 \mathrm{~min})$ and, if necessary, stained with secondary antibody in milk/BSA TBS-T for $1 \mathrm{~h}$ at $\mathrm{rt}$. The blot was washed with TBS-T $(3 \times 5 \mathrm{~min})$ and visualized using Immobilon Crescendo Western HRP substrate, imaging using the chemiluminescence method on an ImageQuant LAS-4000 Imaging System.

\section{Chemical Proteomics}

Lysates for all proteomics experiments were derived from cells cultured in $10 \mathrm{~cm}$ dishes in triplicate for each experimental condition. $600 \mu \mathrm{g}$ of labelled protein clicked to AzRB were enriched on NeutrAvidin agarose, all as described above. All buffers were prepared fresh and filtered $(0.2 \mu \mathrm{m})$ and the work surface cleaned with $70 \%(\mathrm{v} / \mathrm{v}) \mathrm{EtOH}$.

The beads were washed twice with $300 \mu \mathrm{L} 1 \%(\mathrm{w} / \mathrm{v})$ SDS in $50 \mathrm{mM}$ HEPES (pH 8). Proteins were reduced and alkylated with $5 \mathrm{mM}$ TCEP and $10 \mathrm{mM}$ chloroacetamide in $60 \mu \mathrm{L} 50 \mathrm{mM}$ HEPES with moderate shaking for 30 min at rt. The beads were washed 3 times with $300 \mu \mathrm{L}$ $50 \mathrm{mM}$ HEPES. Beads were resuspended in $30 \mu \mathrm{L} 50 \mathrm{mM}$ HEPES and proteins were digested on-bead by treatment with $1 \mu \mathrm{L}$ trypsin (Promega, $20 \mu \mathrm{g}$ dissolved in $100 \mu \mathrm{L} 50 \mathrm{mM}$ HEPES) with vigorous shaking at $37^{\circ} \mathrm{C}$ overnight. The samples were briefly centrifuged and $10 \mu \mathrm{L}$ of the supernatant from each sample was TMT-labelled by combining with $10 \mu \mathrm{L}$ of the appropriate TMT10plex ${ }^{\mathrm{TM}}$ Isobaric Mass Tag Labelling Reagent (Thermo Scientific) dissolved in acetonitrile ( $8 \mathrm{mg} \mathrm{mL}^{-1}$ ) with moderate shaking for $2 \mathrm{~h}$ at $\mathrm{rt}$ (see Extended Data 2 for TMT label used for each sample). TMT-labelling was quenched by the addition of $1.1 \mu \mathrm{L}$ of $5 \%(\mathrm{w} / \mathrm{v})$ 
hydroxylamine and the samples from each TMT set were combined into one "plex" solution. These samples were evaporated to dryness.

\section{6-layer fractionation}

Each stage tip was prepared by cutting $3 \times$ polystyrene-divinylbenzene copolymer modified with sulfonic acid (SCX) disks (3M) and using these to plug a p200 pipette tip. The tip was activated with $150 \mu \mathrm{L} \mathrm{MeCN}$ by centrifugation (3000 $\times \mathrm{g}$, $3 \mathrm{~min}$ ) then equilibrated with $150 \mu \mathrm{L}$ $\mathrm{H}_{2} \mathrm{O}$ by centrifugation $(3000 \times \mathrm{g}, 3 \mathrm{~min})$. Samples were dissolved in $1 \%(\mathrm{v} / \mathrm{v})$ aqueous trifluoroacetic acid and each sample transferred to a stage tip. Peptides were loaded onto the SCX column by centrifugation as above. Peptides were desalted by centrifugation with $3 \times$ $60 \mu \mathrm{L}$ of $0.2 \%(\mathrm{v} / \mathrm{v})$ trifluoroacetic acid. Peptides were then liberated from the column sequentially by centrifugation with $60 \mu \mathrm{L}$ of each of the following buffers into separate Lo-Bind Eppendorfs:

\begin{tabular}{cc}
\hline Fraction & Buffer composition \\
\hline 1 & $75 \mathrm{mM}$ ammonium acetate, $20 \%(\mathrm{v} / \mathrm{v}) \mathrm{MeCN}, 0.5 \%(\mathrm{v} / \mathrm{v})$ Formic Acid \\
2 & $125 \mathrm{mM}$ ammonium acetate, $20 \%(\mathrm{v} / \mathrm{v}) \mathrm{MeCN}, 0.5 \%(\mathrm{v} / \mathrm{v})$ Formic Acid \\
3 & $200 \mathrm{mM}$ ammonium acetate, $20 \%(\mathrm{v} / \mathrm{v}) \mathrm{MeCN}, 0.5 \%(\mathrm{v} / \mathrm{v})$ Formic Acid \\
4 & $300 \mathrm{mM}$ ammonium acetate, $20 \%(\mathrm{v} / \mathrm{v}) \mathrm{MeCN}, 0.5 \%(\mathrm{v} / \mathrm{v})$ Formic Acid \\
5 & $400 \mathrm{mM}$ ammonium acetate, $20 \%(\mathrm{v} / \mathrm{v}) \mathrm{MeCN}, 0.5 \%(\mathrm{v} / \mathrm{v})$ Formic Acid \\
6 & $5 \%(\mathrm{v} / \mathrm{v})$ ammonium hydroxide, $80 \%(\mathrm{v} / \mathrm{v}) \mathrm{MeCN}$ \\
\hline
\end{tabular}

All fractions of each sample were evaporated to dryness and stored at $-80^{\circ} \mathrm{C}$.

\section{LC-MS/MS methodology}

Samples were rehydrated in $0.5 \%(\mathrm{v} / \mathrm{v})$ formic acid, $2 \%(\mathrm{v} / \mathrm{v})$ UPLC grade MeCN in Optima ${ }^{\mathrm{TM}}$ $\mathrm{LC} / \mathrm{MS} \mathrm{H}_{2} \mathrm{O}$ (Fisher Scientific) and dissolved completely by vortexing and sonication. Samples were filtered through $3 \times$ Durapore ${ }^{\circledR}$ membrane filters (Millipore) plugged into a p20 pipette tip by centrifuging the samples through the filters $(4000 \times \mathrm{g}, 5 \mathrm{~min})$ into a mass spectrometry vial. Samples were stored at $4{ }^{\circ} \mathrm{C}$ until ready for analysis.

Peptides were separated on an EASY-Spray ${ }^{\mathrm{TM}}$ Acclaim PepMap $\mathrm{C}_{18}$ column $(50 \mathrm{~cm} \times 75 \mu \mathrm{m}$ inner diameter, Thermo Fisher Scientific) using a 3-hour linear gradient separation of $0-100 \%$ solvent B $(80 \%$ MeCN supplemented with $0.1 \%$ formic acid): solvent $A(2 \% \mathrm{MeCN}$ supplemented with $0.1 \%$ formic acid) at a flow rate of $250 \mathrm{~nL} \mathrm{~min}{ }^{-1}$. The liquid chromatography was coupled to a QExactive mass spectrometer via an easy-spray source (Thermo Fisher Scientific) which operated in data-dependent mode with survey scans acquired at a resolution of 70,000 at $\mathrm{m} / \mathrm{z} 200$. Scans were acquired from 350 to $1800 \mathrm{~m} / \mathrm{z}$. Up to 10 of the most abundant isotope patterns with charge +2 or higher from the survey scan were selected with an isolation window of $1.6 \mathrm{~m} / \mathrm{z}$ and fragmented by HCD with normalized collision energy of 25 . The maximum ion injection times for the survey scan and the MS/MS scans (acquired with a resolution of 35,000 at $\mathrm{m} / \mathrm{z} 200$ ) were 20 and $120 \mathrm{~ms}$, respectively. The ion target value for MS was set to $10^{6}$ and for MS/MS to $10^{5}$, and the intensity threshold was set to $8.3 \times 10^{2}$.

\section{Data analysis}

Peptide searches were performed in MaxQuant version 1.6.0.2. Under group-specific parameters and type, reporter ion MS2 was selected, and the appropriate TMT10plex ${ }^{\mathrm{TM}}$ isobaric labels selected for both lysines and $\mathrm{N}$-termini. For all experiments, oxidation (M) and acetyl (protein $\mathrm{N}$-term) were set as variable modifications, carbamidomethyl (C) was set as a fixed modification, trypsin/P was set as the digestion mode, re-quantify and match between runs were selected, and up to date UniProt FASTA files for the human proteome and contaminants databases were used. 
Data analysis was performed in Perseus version 1.6.7.0. Reporter intensity corrected values were loaded into the matrix. Data was filtered by removing rows based on "only identified by site", "reverse", and "potential contaminant" columns. Data were $\log _{2}$ transformed and filtered by row, retaining those that had 2 valid values in each triplicate condition. TMT data were normalized by subtracting the mean of each row within each TMT "plex" (if appropriate) and subtracting the median of each column. Volcano plots were generated using a pairwise Student's T-Test and the cut-offs generated using the false discovery rate (FDR) and $\mathrm{S}_{0}$ values indicated.

\section{PARP6 auto-ADP ribosylation assay}

This protocol was adapted from Hutin, Grimaldi and Matthews. ${ }^{4}$ Briefly, reaction tubes containing $1 \times$ assay buffer $(20 \times$ : $1 \mathrm{M}$ Tris- $\mathrm{HCl}$, pH 8.0, $4 \mathrm{mM}$ DTT, $80 \mathrm{mM} \mathrm{MgCl}$ ), $25 \mu \mathrm{M}$ NAD+-biotin (added last), $0.3 \mu \mathrm{M}$ GST-PARP6, appropriate concentration of inhibitor (from 10x stock ( $1 \%(\mathrm{v} / \mathrm{v})$ DMSO)) were made up to final volume with $\mathrm{H}_{2} \mathrm{O}$, substituting for appropriate controls. The reactions were shaken on ice for $30 \mathrm{~min}$, quenched with $4 \times$ sample loading buffer and boiled at $95{ }^{\circ} \mathrm{C}$ for $5 \mathrm{~min}$. The samples were separated on to two SDS-PAGE gels and transferred to nitrocellulose. Each membrane was blotted separately using NeutrAvidin-HRP and anti-PARP6 (total protein).

\section{Transfection}

\section{Plasmid production}

All microbiology work was carried out in a work area sterilized with $70 \%(\mathrm{v} / \mathrm{v}) \mathrm{EtOH}$ and in the presence of an open flame. All equipment and media was either bought sterile or sterilized by autoclave. DNA concentration was measured using a NanoDrop OneC (Thermo Scientific). Sequencing was performed by Genewiz.

$1 \mu \mathrm{L}$ of pcDNA ${ }^{\mathrm{TM}} 3.1$ plasmid $\left(70 \mathrm{ng} \mu \mathrm{L}^{-1}\right)$ containing FLAG-PARP6 was transformed into $50 \mu \mathrm{L}$ competent DH5 $\alpha$ E. coli cells (Invitrogen) by heat shock treatment (30 min on ice, $42{ }^{\circ} \mathrm{C}$ for $45 \mathrm{~s}, 2$ min on ice). Cells were cultured in Super Optimal broth with Catabolite repression (S. O. C.) medium ( $\left.1 \mathrm{~h}, 900 \mathrm{rpm}, 37^{\circ} \mathrm{C}\right)$ then $50 \mu \mathrm{L}$ spread on lysogeny broth (LB) agar supplemented with $100 \mu \mathrm{g} \mu \mathrm{L}^{-1}$ ampicillin which was grown overnight at $37^{\circ} \mathrm{C}$. Individual colonies were then cultured overnight $\left(37^{\circ} \mathrm{C}, 170 \mathrm{rpm}\right)$ in $15 \mathrm{~mL}$ LB medium supplemented with $100 \mu \mathrm{g} \mathrm{L}^{-1}$ ampicillin. $5 \mathrm{~mL}$ of this culture was used to inoculate a further $150 \mathrm{~mL} \mathrm{LB}$ medium supplemented with $100 \mu \mathrm{g} \mathrm{L}^{-1}$ ampicillin and grown overnight ( $37^{\circ} \mathrm{C}, 170 \mathrm{rpm}$ ). Plasmids were purified from the culture using the QIAGEN® Maxiprep kit and sequence identity confirmed by Sanger sequencing.

\section{Mammalian cell uptake}

Transfections were performed with Lipofectamine ${ }^{\circledR}$ LTX with Plus ${ }^{\mathrm{TM}}$ Reagent according to standard manufacturer's protocol. Briefly, MDA-MB-468 cells were seeded in sterile treated 6well plates and grown to confluency. Transfections were performed at 1:3 DNA:Lipofectamine with $2 \mu \mathrm{g}$ DNA, incubating for $24 \mathrm{~h}$. Cells were then treated and irradiated as described above and analyzed by in-gel fluorescence and western blot.

\section{Lysate-based photocrosslinking assay}

Native MDA-MB-468 lysates were generated by trypsination of one $75 \mathrm{~cm}^{2}$ flask of cells as described above. Trypsin was quenched and removed by aspiration after centrifugation (200 $\times$ g, $5 \mathrm{~min})$. The cells were washed similarly in PBS and resuspended in cold PBS $(250 \mu \mathrm{L})$. Cells were lysed on ice by probe sonication (20\% amplitude, $18 \mathrm{~s}$ ( $3 \mathrm{~s}$ pulse, $3 \mathrm{~s}$ rest)) and centrifuged to remove cell debris. Protein concentration was determined as above and the lysate snap frozen in liquid $\mathrm{N}_{2}$ and stored at $-80^{\circ} \mathrm{C}$. Lysates were thawed on ice before use. 
In a clear 96-well plate, wells containing $2 \mathrm{mg} \mathrm{mL}^{-1}$ native MDA-MB-468 lysate, $0.1 \mu \mathrm{M}$ GSTPARP6 (or blank storage buffer), appropriate concentration of PARPYnD/AZ0108 (from 100x stock (10\% (v/v) DMSO) - added last) were made up to final volume with PBS and incubated on ice for $30 \mathrm{~min}$ in the dark. The plate was irradiated with UV light for $5 \mathrm{~min}(365 \mathrm{~nm}$ monochromatic) and each sample transferred to Eppendorfs. The proteins were precipitated as described above to remove Tris (in GST-PARP6 storage buffer) which would otherwise inhibit the click reaction. Proteins were clicked to AzTB and enriched as described above, and the results analyzed by gel and western blot.

Variation with Prescission ${ }^{\mathrm{TM}}$ Protease

When also treating the samples with PreScission ${ }^{\mathrm{TM}}$ Preotease, samples were made up with the cleavage buffer (50 mM Tris- $\mathrm{HCl}, 150 \mathrm{mM} \mathrm{NaCl}, 1 \mathrm{mM}$ EDTA, $1 \mathrm{mM}$ DTT, pH 7.0) rather than PBS, and GST-PARP6 was added to a concentration of $0.3 \mu \mathrm{M}$. Cleavage was performed using $1 \mathrm{U}$ of enzyme overnight with moderate shaking at $4{ }^{\circ} \mathrm{C}$. Samples were irradiated and prepared for gel-based analysis as described above. 


\section{Supporting Schemes}

Scheme S1 - Synthesis of PARPYnD.
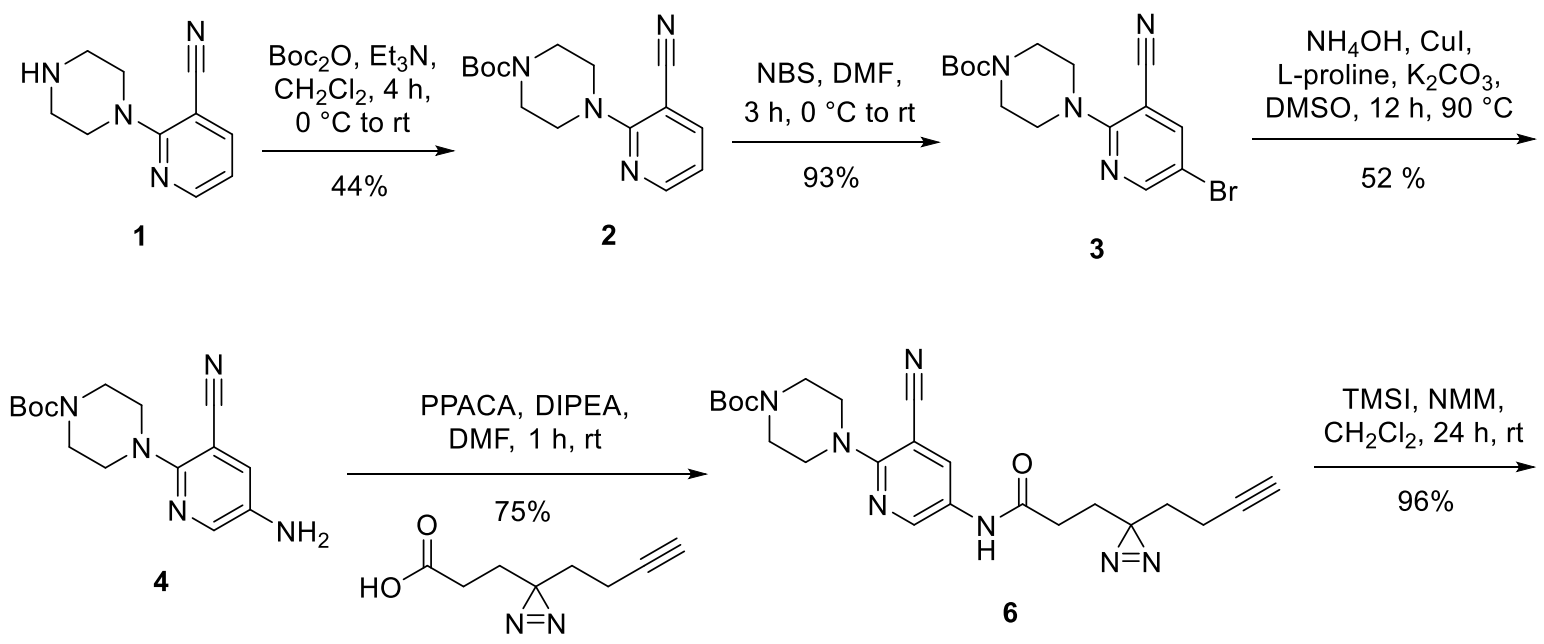

5

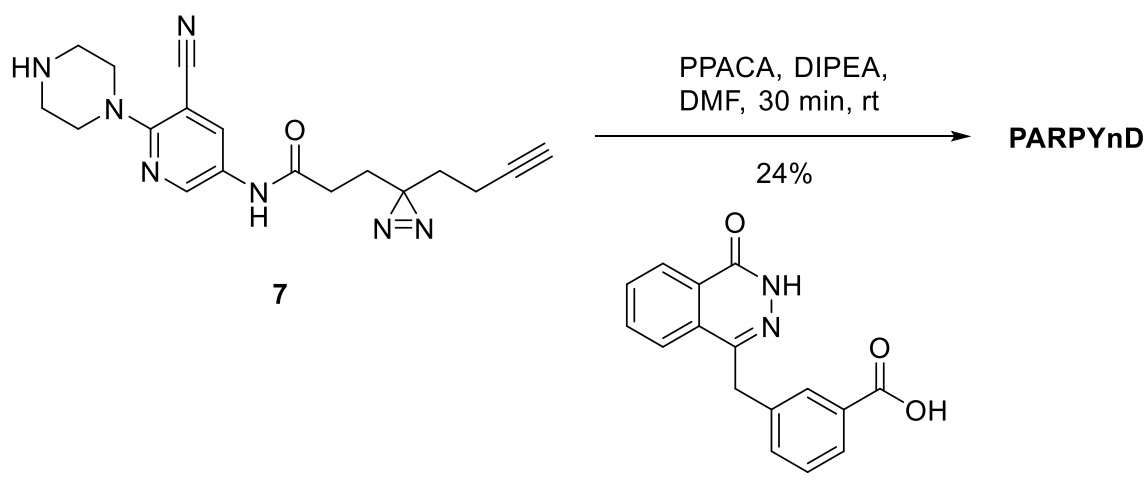




\section{Supporting Figures}

Figure S1. PARP in vitro binding assays.

Dose-response curves for PARPYnD tested in fluorescence anisotropy competition assay with various recombinant PARP enzymes. $\mathrm{N}$, number of biological replicates - data displayed \pm SEM of these replicates, fit to 4 parameter dose-response function. PARP1 $I C_{50}=0.038 \mu \mathrm{M}$, PARP2 $I_{50}=0.006 \mu \mathrm{M}$, PARP6 $\mathrm{IC}_{50}=0.230 \mu \mathrm{M}$. Raw data can be found in Extended Data 1.

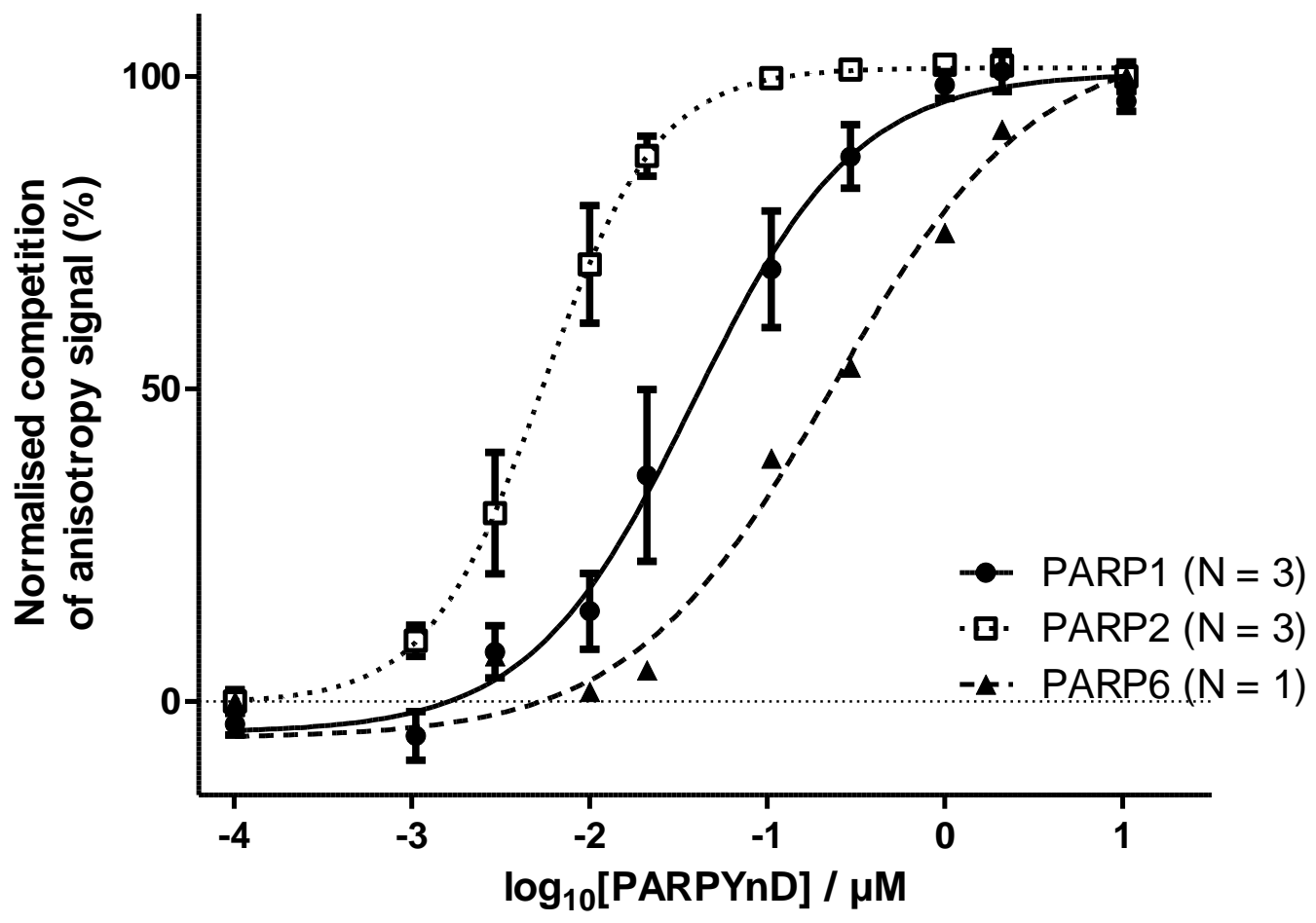


Figure S2. Cell viability assay.

Dose-response curves for MDA-MB-468 cells treated with varying concentrations of each compound indicated for 3 days. Cell viability was measured using the MTS assay, \% survival was measured relative to $0.1 \%(\mathrm{v} / \mathrm{v})$ DMSO control. Raw survival values are displayed in the table below. Data points are average of three technical replicates $( \pm S E M)$, data fit to 3

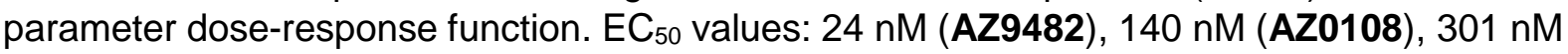
(PARPYnD).

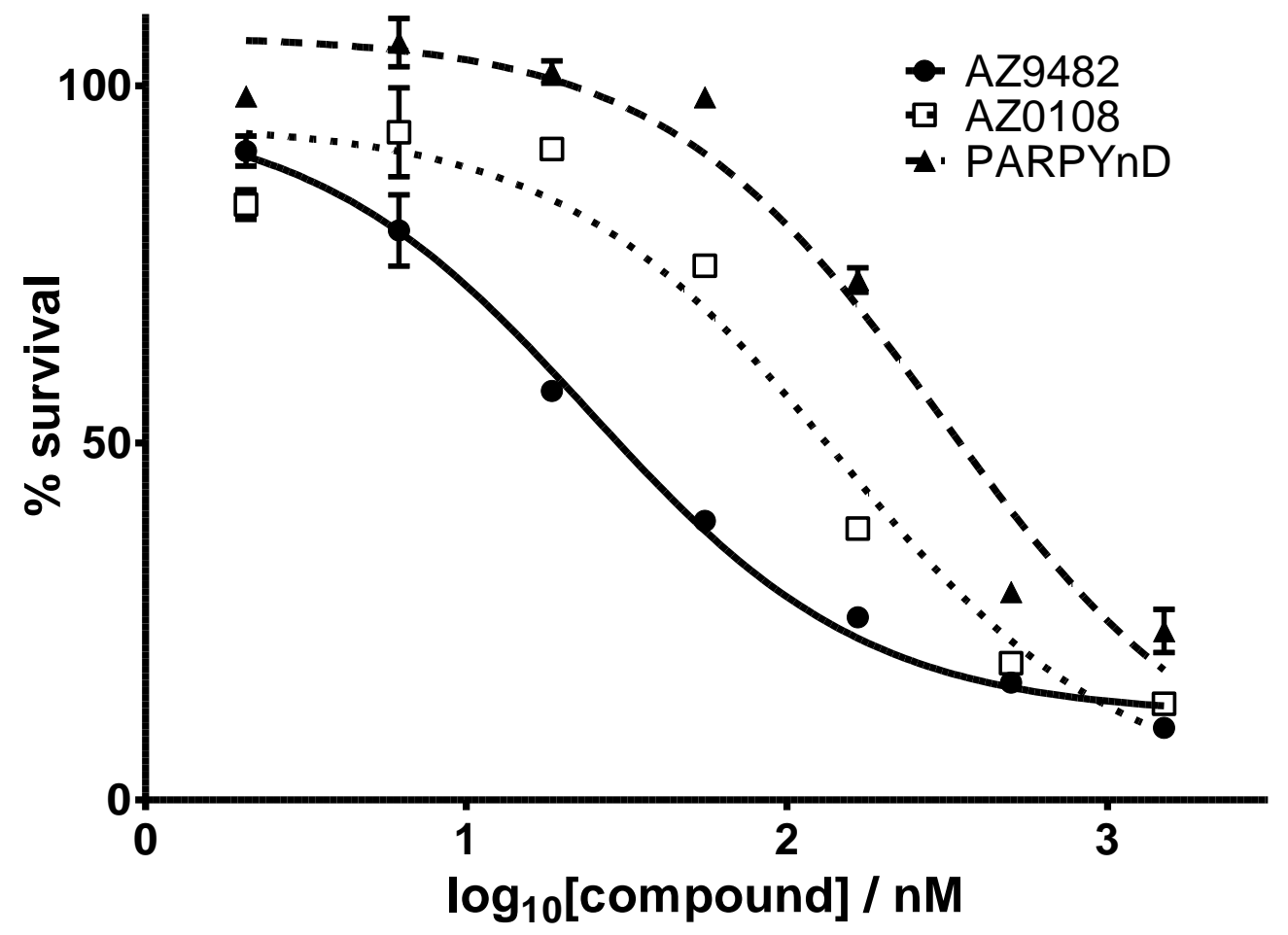

\begin{tabular}{c|ccc|ccc|ccc}
\hline $\log _{10}[$ compound] / nM & \multicolumn{3}{|c|}{ AZ9482 } & \multicolumn{3}{c|}{ AZ0108 } & \multicolumn{3}{c}{ PARPYnD } \\
\hline 0.31 & 92.9 & 86.7 & 92.9 & 79.7 & 83.7 & 86.7 & 97.2 & 98.6 & 99.6 \\
0.79 & 88.2 & 70.9 & 80.1 & 86.9 & 87.7 & 105.9 & 105.4 & 100.5 & 112.1 \\
1.27 & 57.2 & 58.7 & 55.9 & 90.9 & 91.5 & 91.1 & 102.9 & 103.9 & 98.9 \\
1.74 & 37.9 & 38.5 & 40.8 & 74.3 & 76.8 & 73.4 & 96.0 & 98.8 & 100.3 \\
2.22 & 25.8 & 26.4 & 24.5 & 35.6 & 39.1 & 39.3 & 71.4 & 76.2 & 70.7 \\
2.70 & 17.8 & 15.6 & 15.9 & 20.0 & 17.3 & 20.2 & 30.0 & 28.0 & 29.3 \\
3.18 & 7.7 & 10.9 & 11.7 & 13.2 & 13.0 & 14.3 & 28.3 & 24.6 & 18.0 \\
\hline
\end{tabular}


Figure S3. Structure of the clickable capture reagents.

(A) AzTB - Azide-TAMRA-Biotin and (B) AzRB - Azide-Arginine-Biotin. ${ }^{1}$<smiles></smiles>

\section{AzTB}<smiles>N=C(N)NCCC[C@H](NC(=O)CN)C(=O)NCC(=O)NCCCCCC(=O)NCCCOCCOCCOCCCNC(=O)CCCC[C@@H]1SC[C@@H]2NC(=O)N[C@H]12</smiles>

AzRB 
Figure S4. Photocrosslinking dose-response assay up to $10 \mu \mathrm{M}$.

MDA-MB-468 cells were treated with up to $10 \mu \mathrm{M}$ PARPYnD for $3 \mathrm{~h}$, irradiated ( $365 \mathrm{~nm}$ ), lysed and ligated to AzTB (Figure S3). Samples were enriched on magnetic streptavidin beads and both lysate (input) and pull down were analyzed by in-gel fluorescence and immunoblot. PARP6 cannot be detected in the enriched fraction over any concentration of PARPYnD up to $10 \mu \mathrm{M}$, over 10 times the reported $\mathrm{IC}_{50}$.

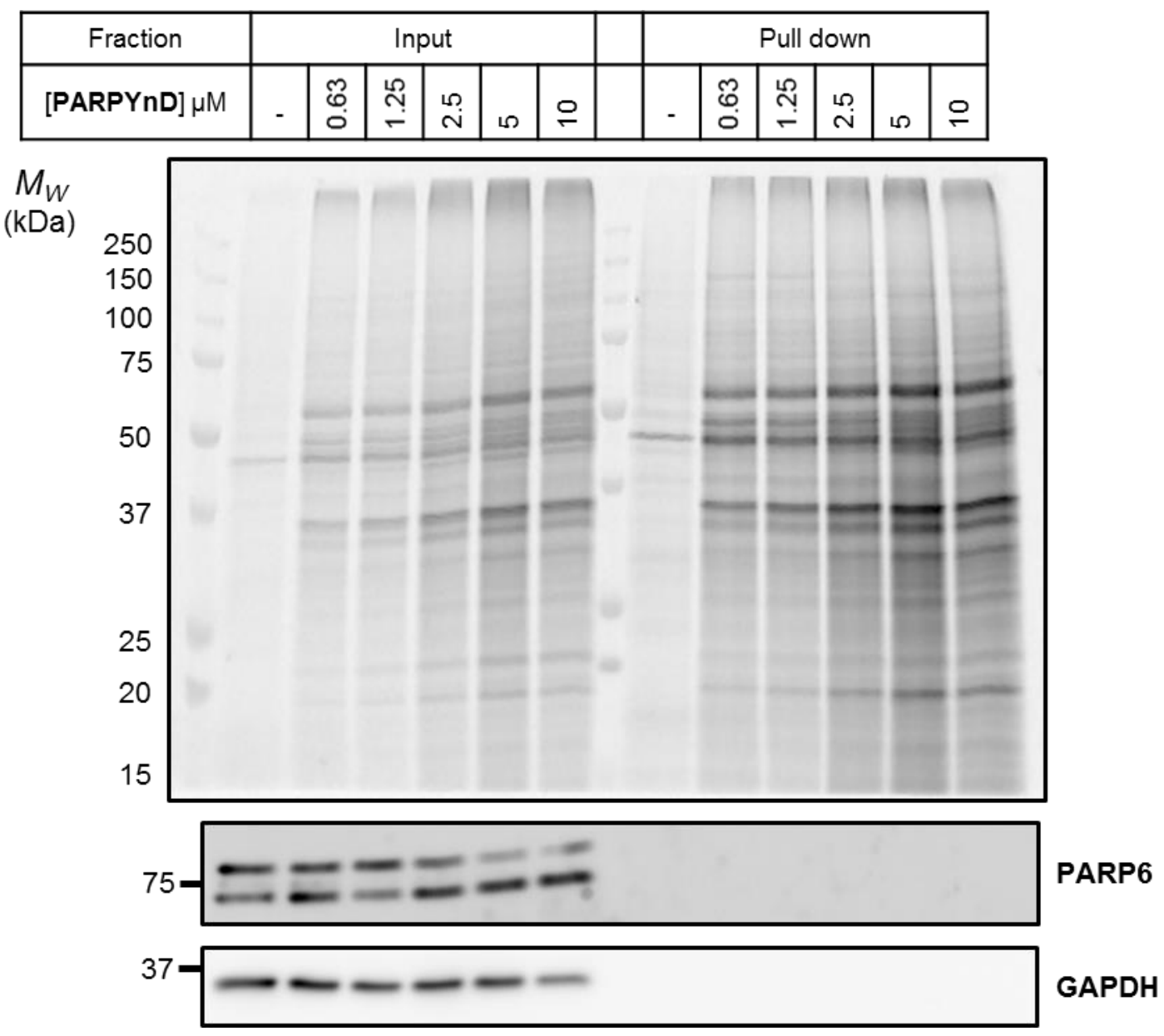


Figure S5. Supplementary volcano and profile plots for PARPYnD.

A-D: Complete annotated volcano plots for Figure 3. Volcano plots demonstrate enrichment ( $x$ axis) of one sample versus another and the associated significance ( $y$ axis), determined by pairwise Student's T-test.

(A) PARPYnD $(1 \mu \mathrm{M})$ vs. DMSO $\left(\mathrm{S}_{0}=0.1, \mathrm{FDR}=0.05\right)$.

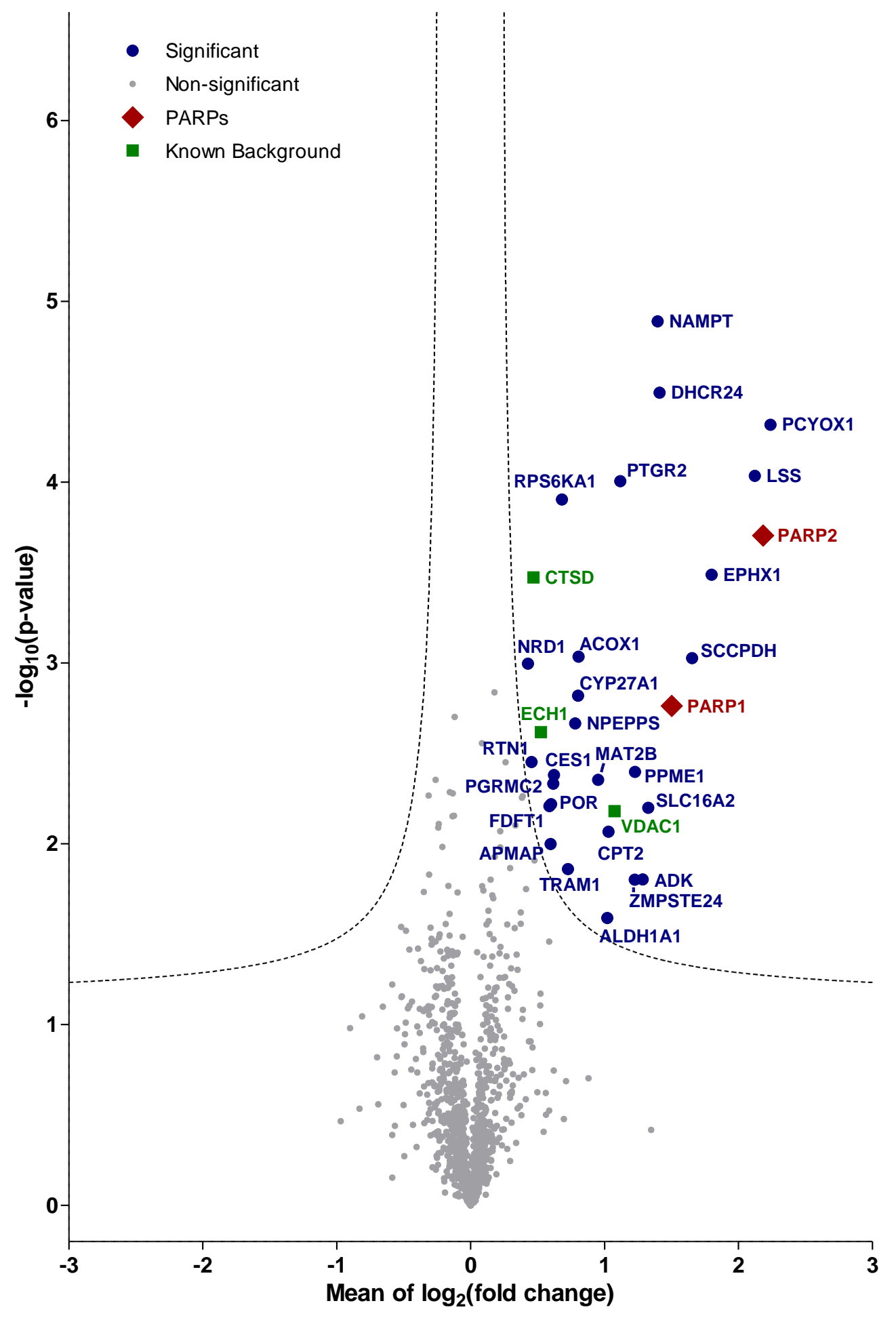


(B) PARPYnD $(1 \mu \mathrm{M})$ and AZ9482 $(5 \mu \mathrm{M})$ vs. PARPYnD $(1 \mu \mathrm{M})$ only $\left(\mathrm{S}_{0}=0.1, \mathrm{FDR}=0.15\right)$.

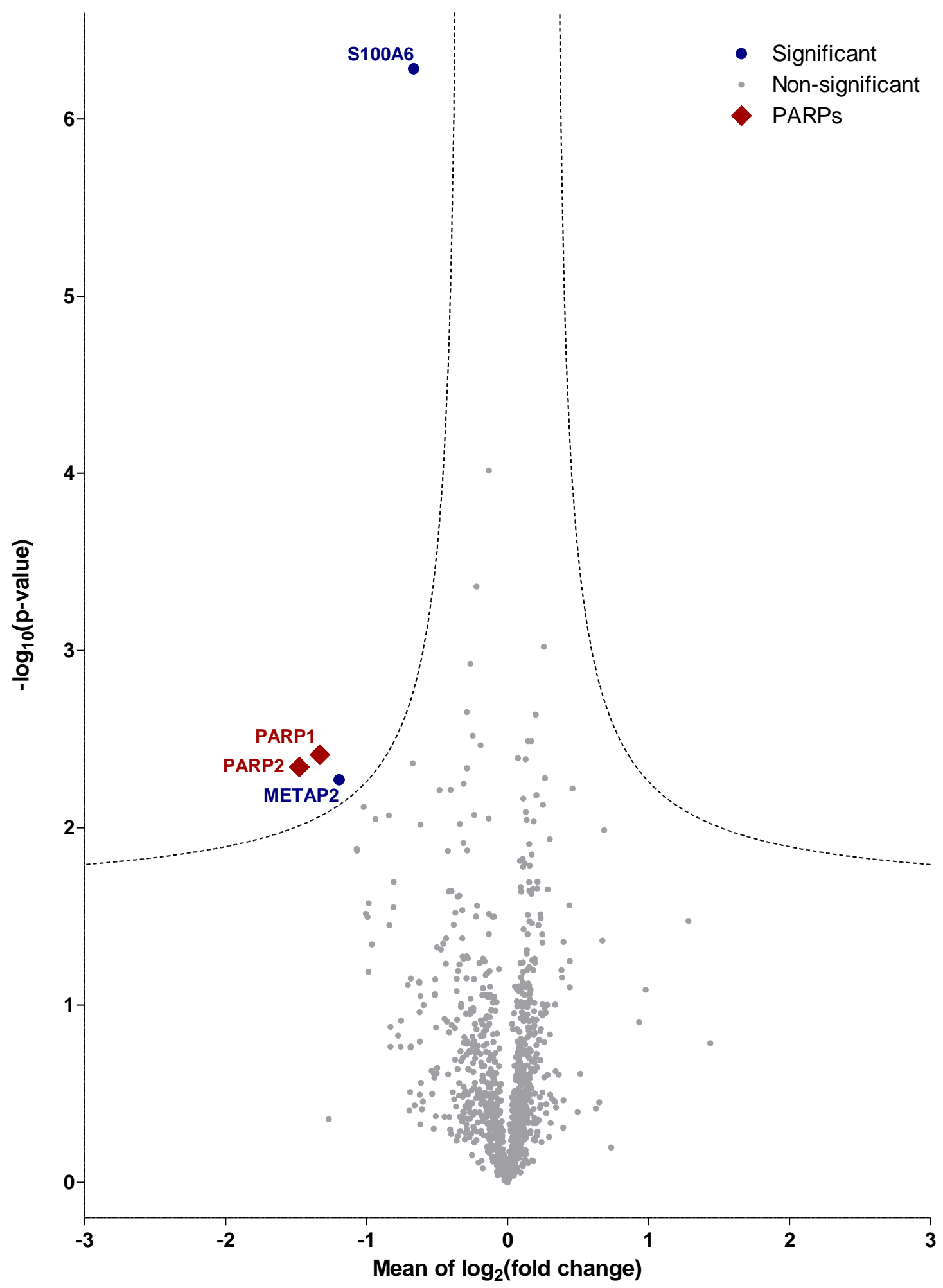


(C) PARPYnD $(1 \mu \mathrm{M})$ and AZ0108 $(5 \mu \mathrm{M})$ vs. PARPYnD $(1 \mu \mathrm{M})$ only $\left(\mathrm{S}_{0}=0.1, \mathrm{FDR}=0.15\right)$.

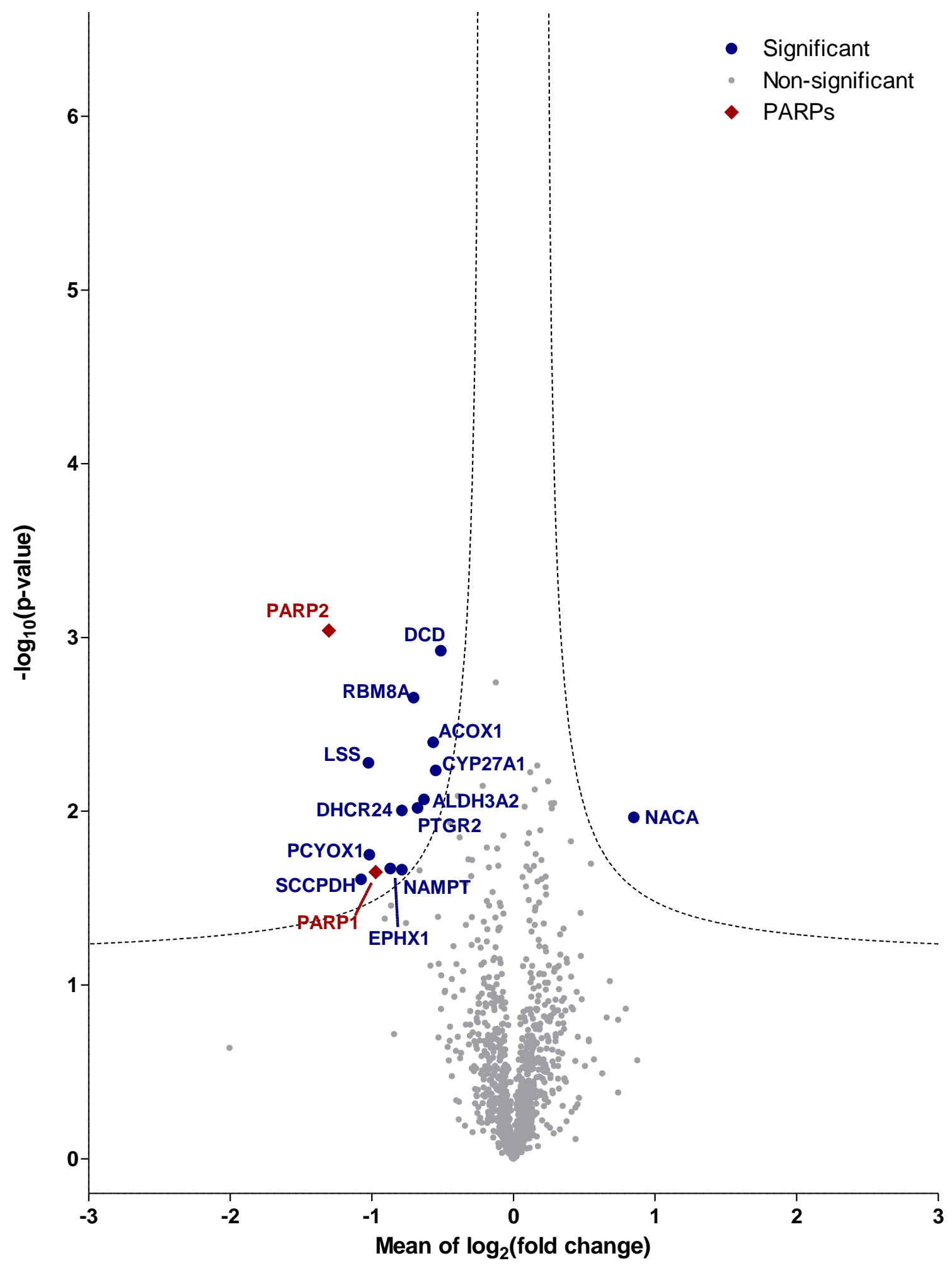


(D) PARPYnD $(1 \mu \mathrm{M})$ and olaparib $(5 \mu \mathrm{M})$ vs. PARPYnD $(1 \mu \mathrm{M})$ only $\left(\mathrm{S}_{0}=0.1, \mathrm{FDR}=0.15\right)$.

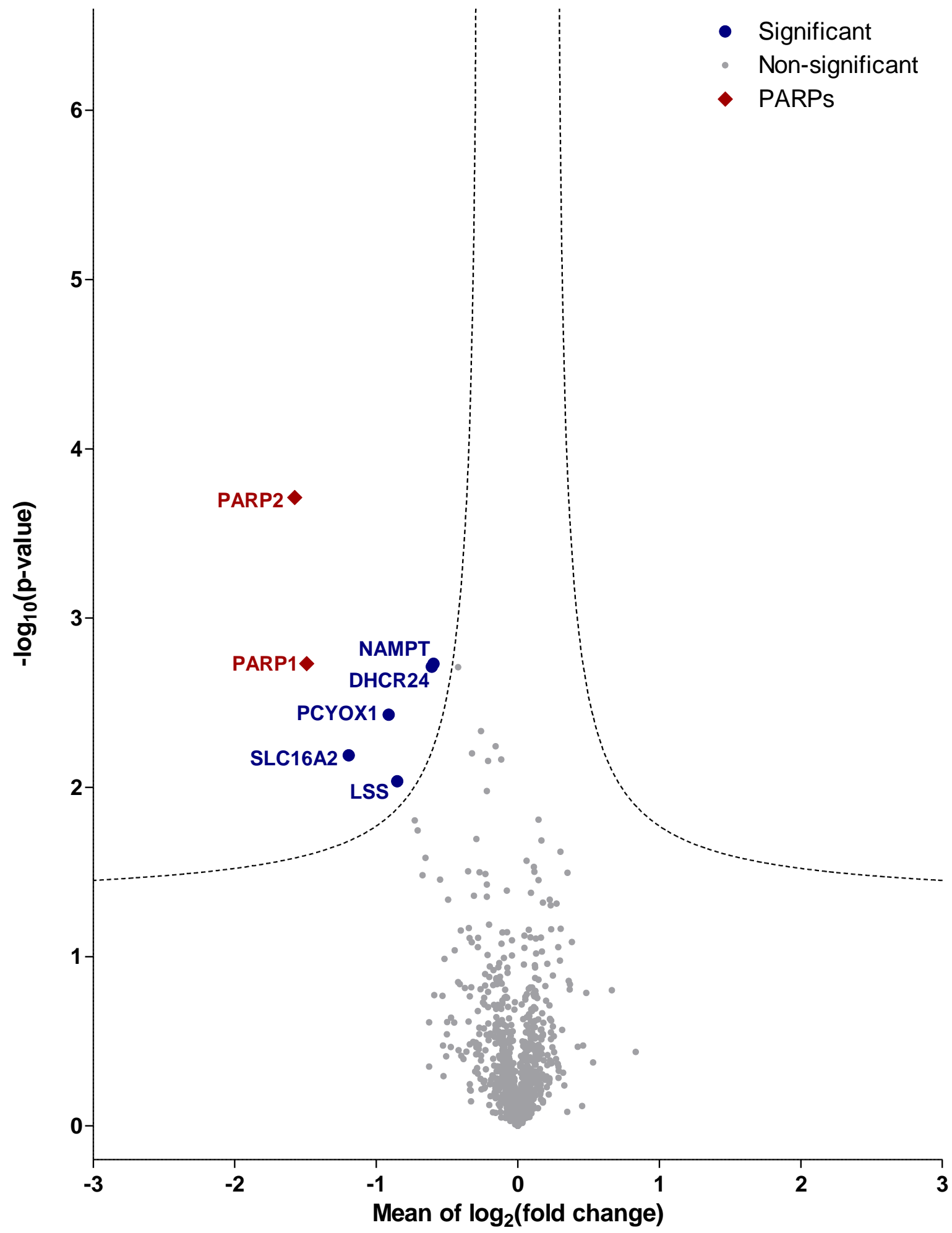


E-G: Complete annotated volcano plots for a separate proteomics experiment demonstrating the UV-dependence of target labelling. MDA-MB-468 cells were treated with PARPYnD $(1 \mu \mathrm{M})$ or DMSO for 3 hours and either irradiated with $365 \mathrm{~nm}$ UV light or kept in the dark. Labelled proteins were enriched, identified and compared pairwise as previously described (Figure 3).

(E) PARPYnD $(1 \mu \mathrm{M})+\mathrm{UV}$ vs. DMSO $+\mathrm{UV}\left(\mathrm{S}_{0}=1, \mathrm{FDR}=0.01\right)$.

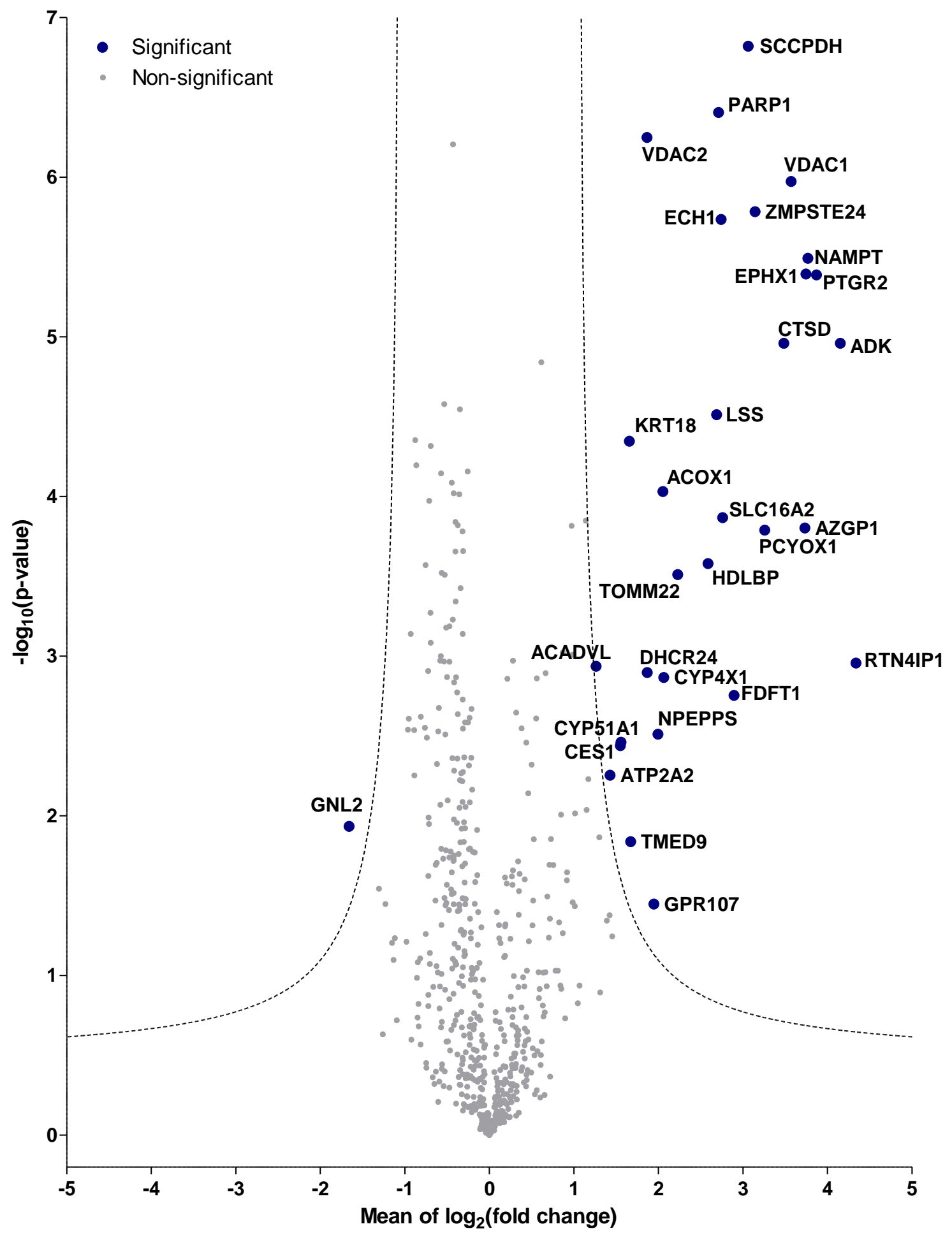


(F) PARPYnD $(1 \mu \mathrm{M})+U V$ vs. PARPYnD $(1 \mu \mathrm{M}) \underline{\text { no UV }}\left(\mathrm{S}_{0}=1, \mathrm{FDR}=0.01\right)$

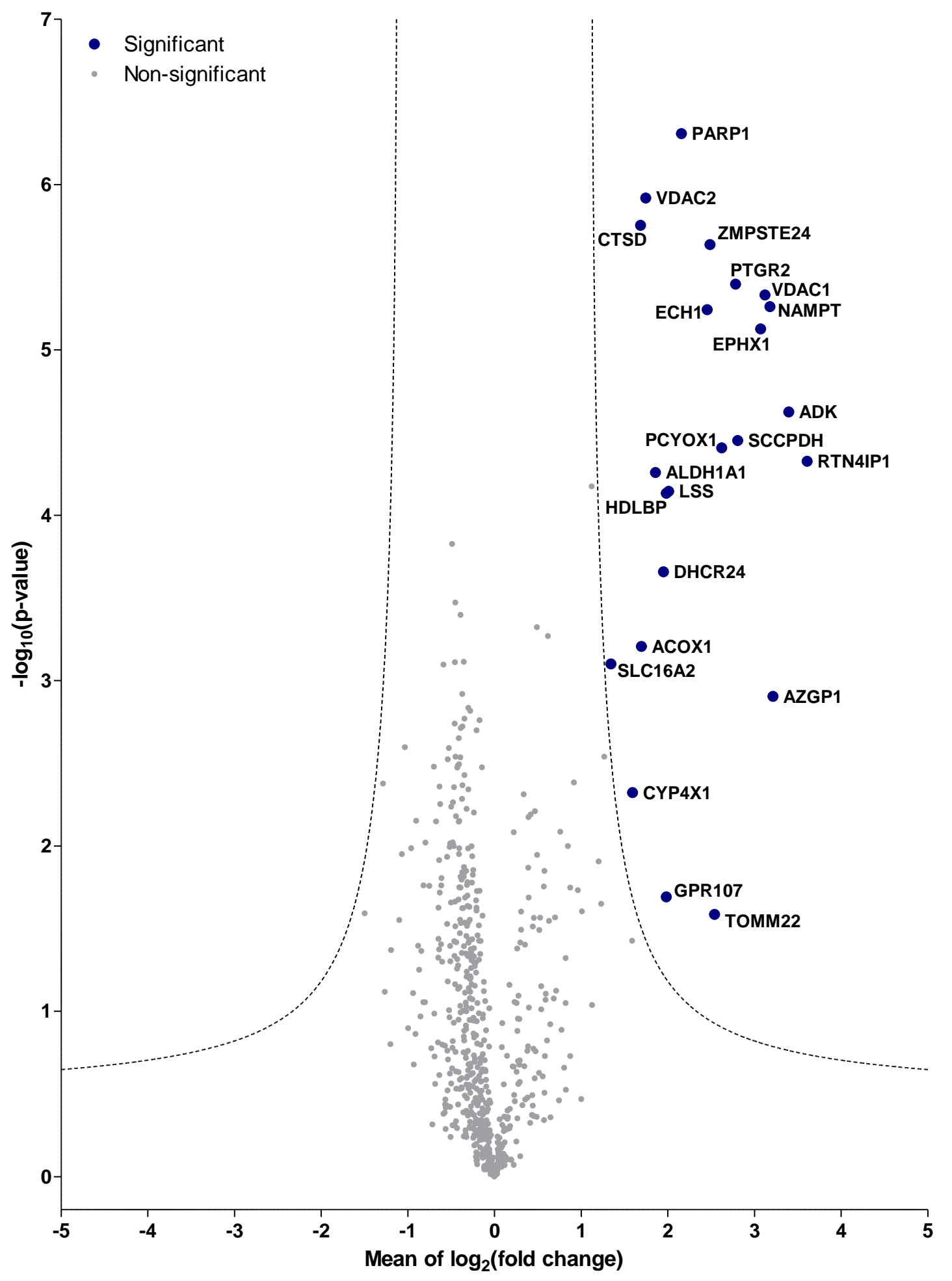


(G) PARPYnD $(1 \mu \mathrm{M}) \underline{\text { no UV }}$ vs. DMSO $\left(\mathrm{S}_{0}=1, \mathrm{FDR}=0.01\right)$

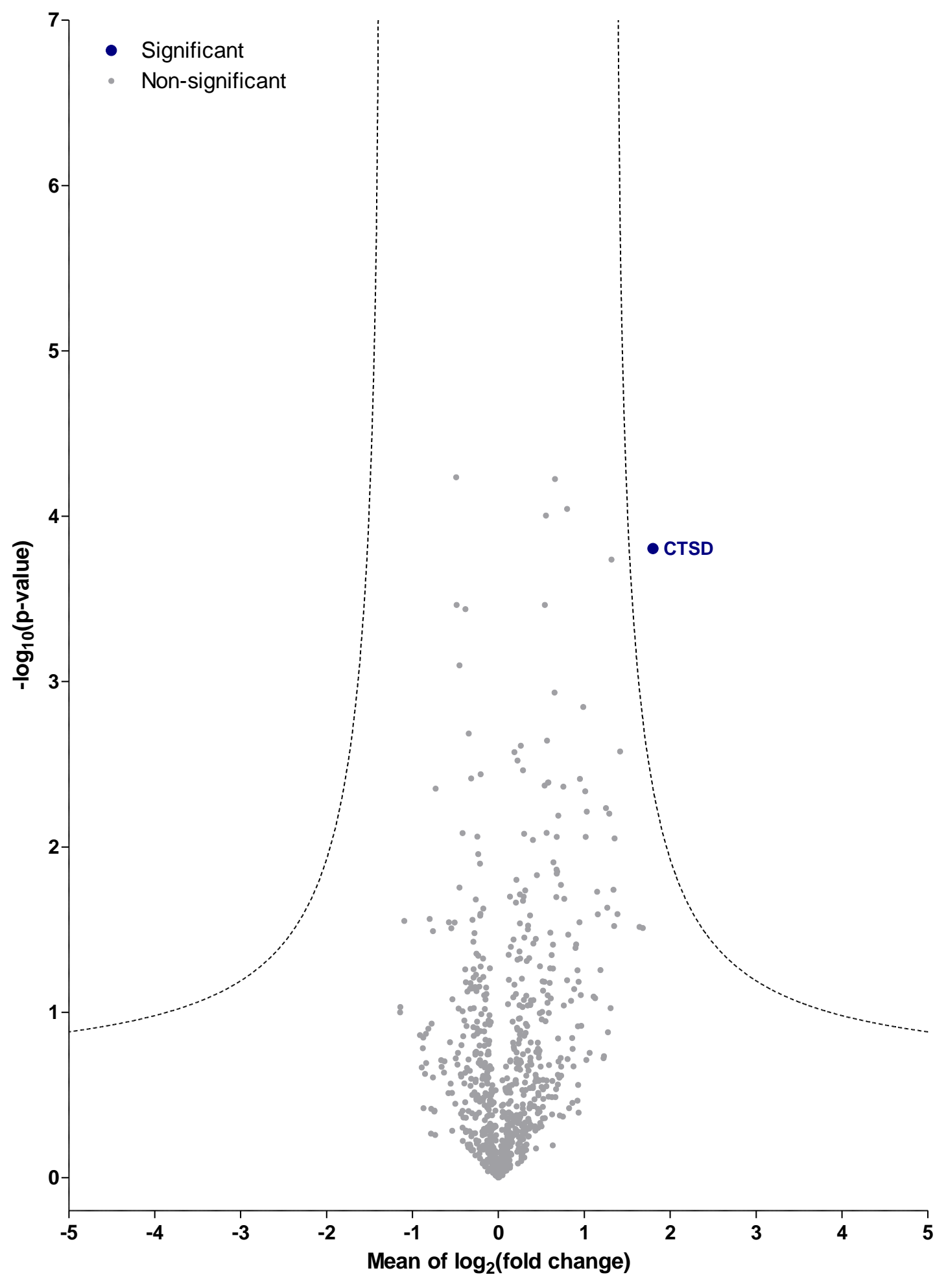


Figure S6. Crosslinking with cleavage experiment.

In-gel fluorescence of PARPYnD labelled lysate with PARP6 \pm cleavage with PreScission ${ }^{\mathrm{TM}}$ Protease. GST tag was found to have no effect on binding and/or labelling. Cleaving the tag off after labelling (lanes 4-6) shows that the $71 \mathrm{kDa}$ PARP6 portion of the protein is labelled ${ }^{*}$ ). Cleaving the tag off before labelling (lanes 7-9) shows that the GST tag does not bias the recombinant protein towards compound binding.

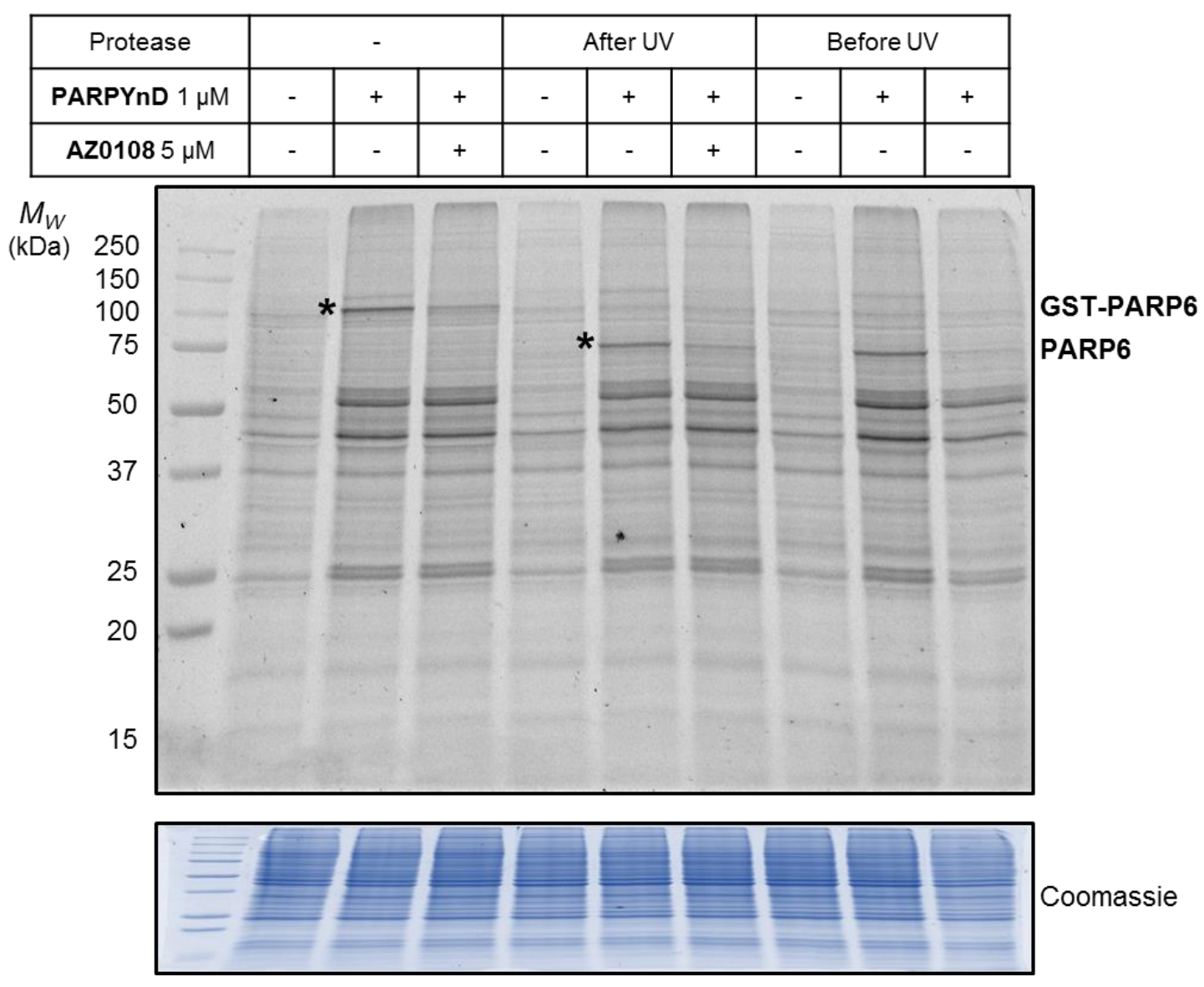


Figure S7. Uncropped gels and immunoblots.

Black boxes indicate portions of the blots taken for figures. Where there is no black box, the whole signal was cropped out and used; I = Input, $\mathrm{P}=$ Pull-down fraction, NA = NeutrAvidin.

\section{Figure S2C}

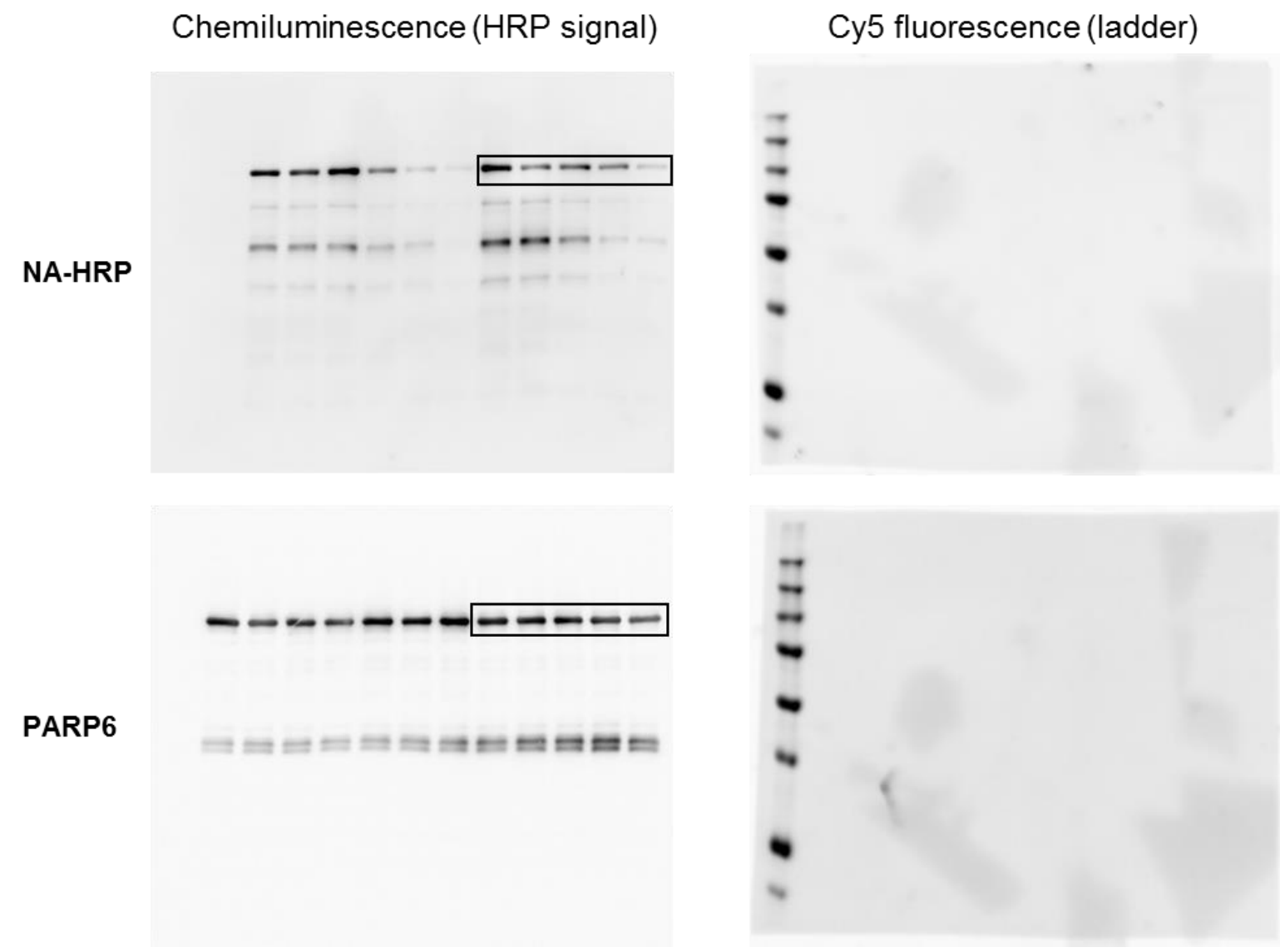

\section{Figure S2D}

TAMRA fluorescence (in-gel)






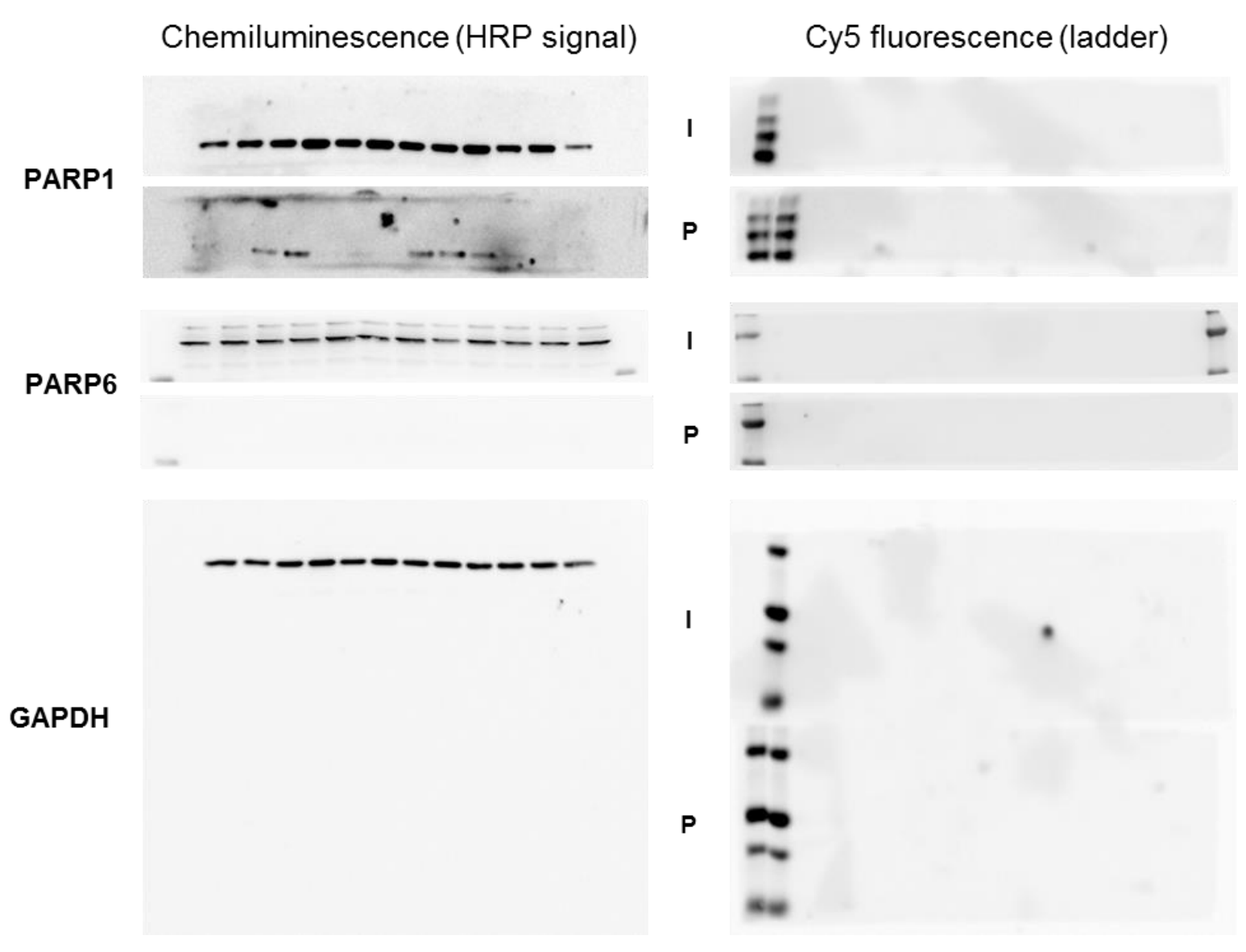


Figure 3E

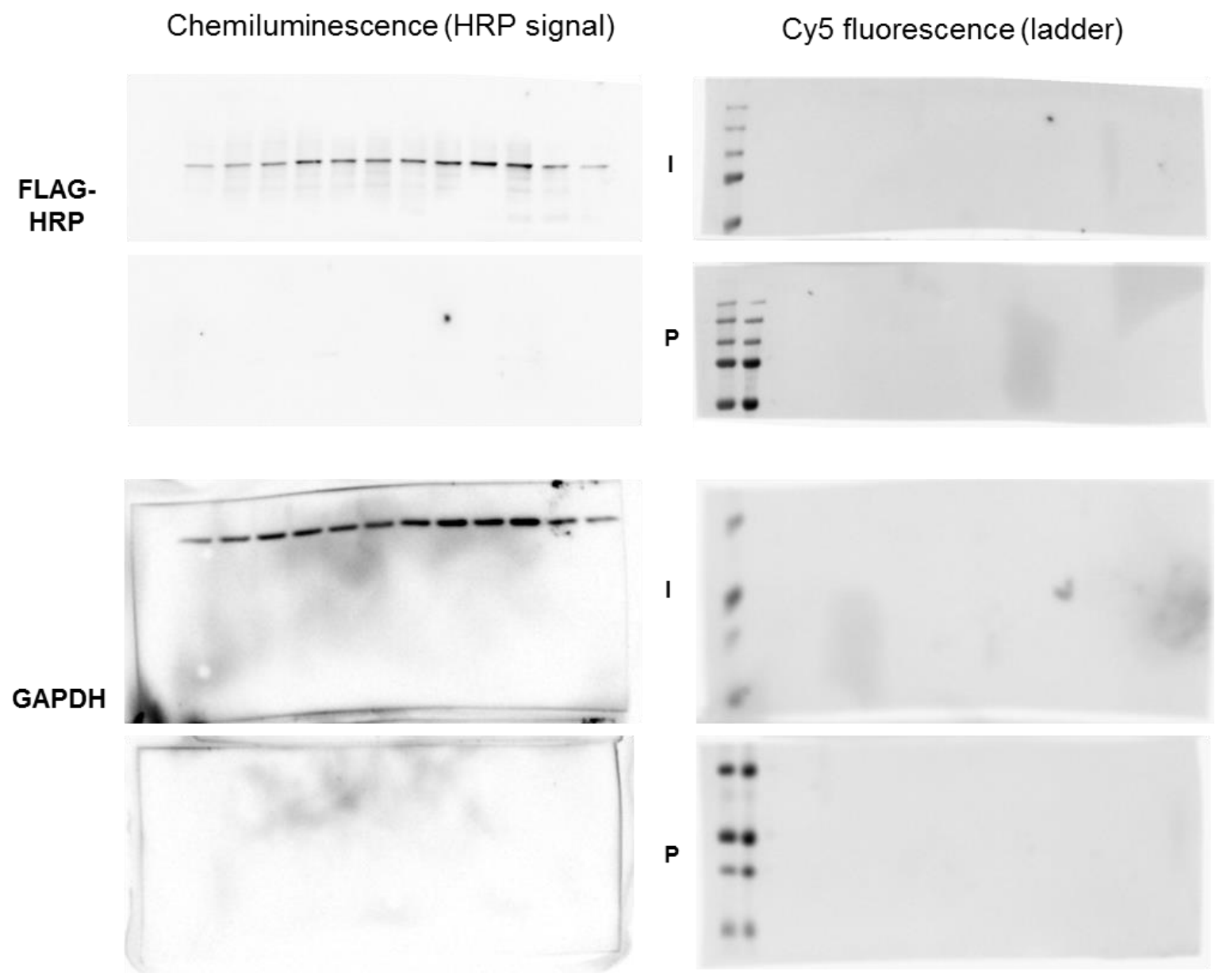

Figure 4

TAMRA fluorescence (in-gel)

+ Recombinant GST-PARP6

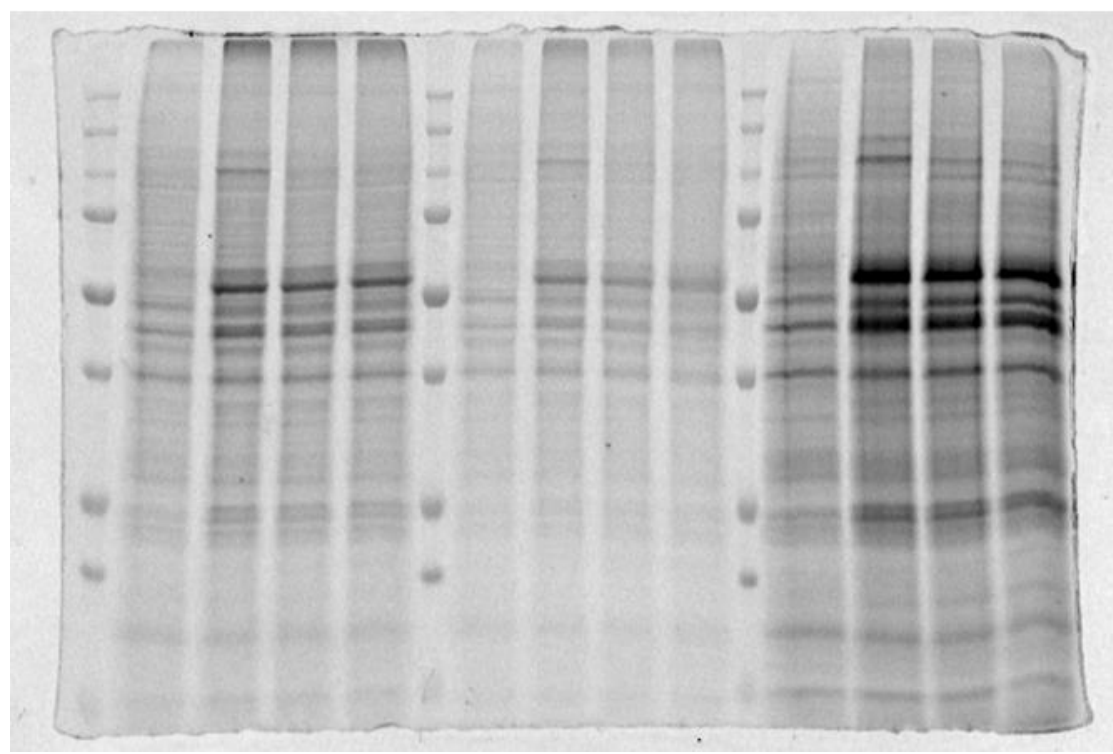


- Recombinant GST-PARP6

Figure S4

Chemiluminescence (HRP signal)

PARP6

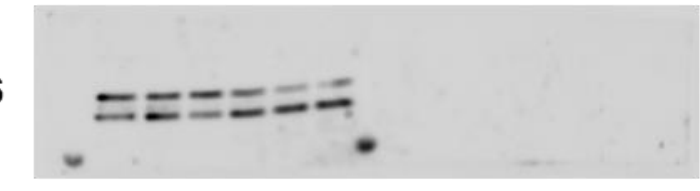

GAPDH

\section{$\underline{\text { Figure S6 }}$}

TAMRA fluorescence (in-gel)

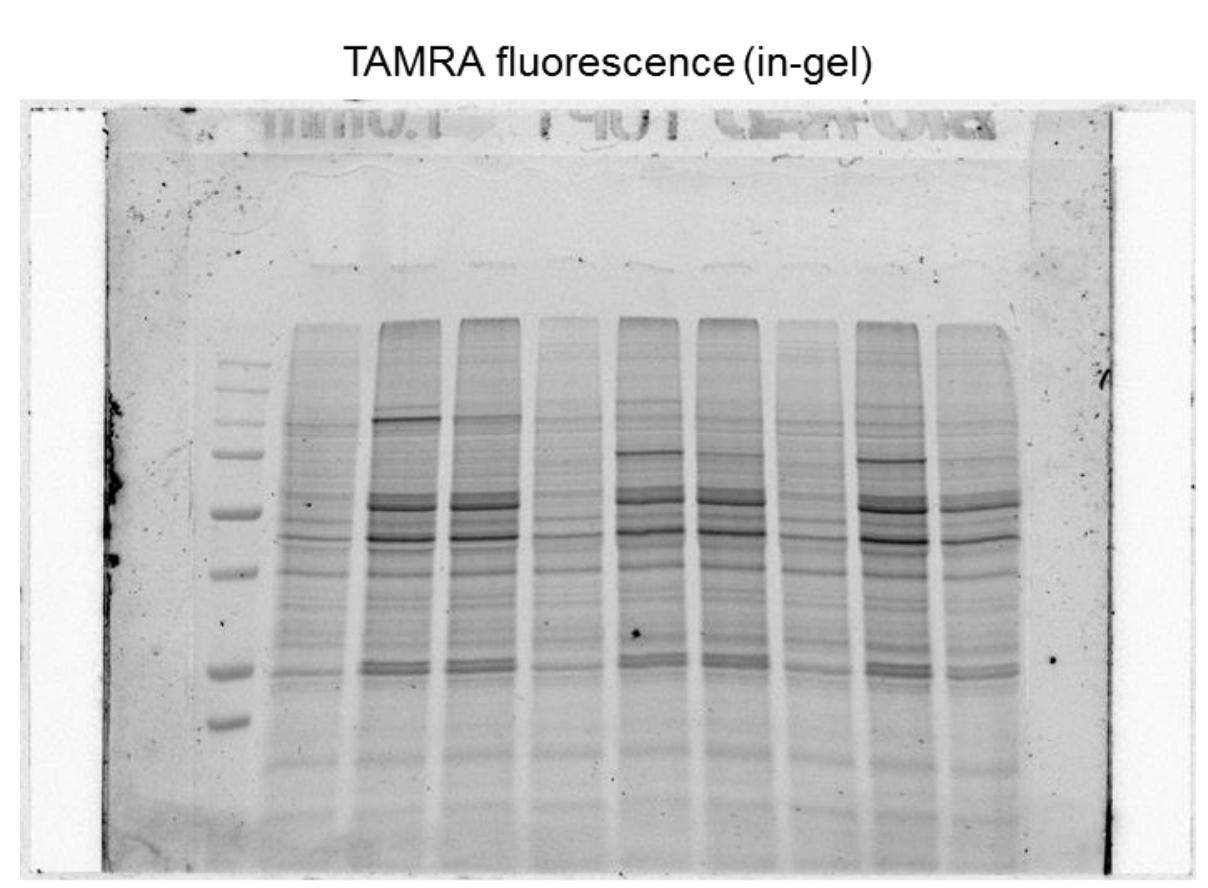

Coomassie

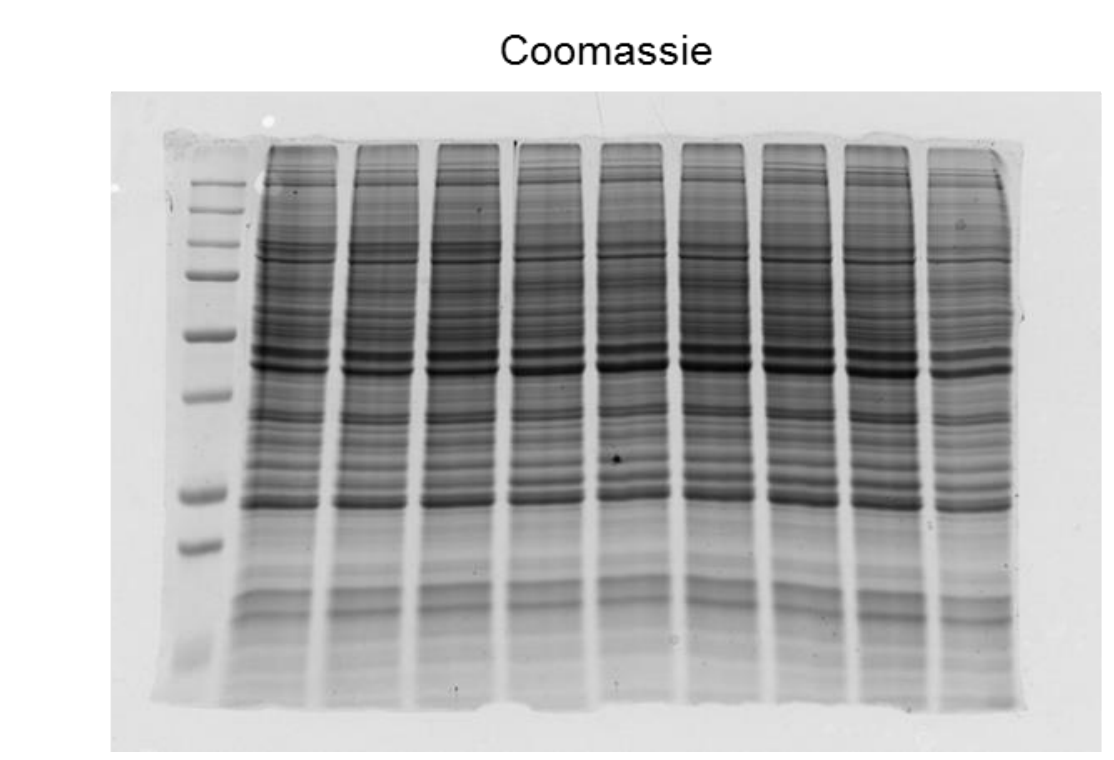

Cy5 fluorescence (ladder)

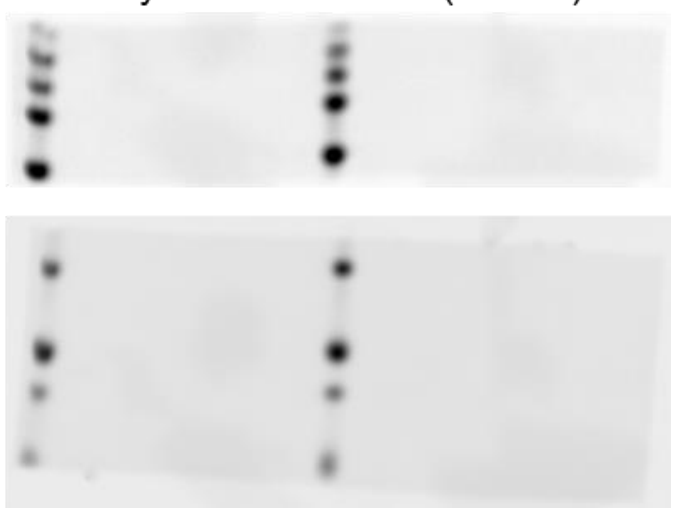




\section{Supporting references}

(1) Broncel, M., Serwa, R. A., Ciepla, P., Krause, E., Dallman, M. J., Magee, A. I., and Tate, E. W. (2015) Multifunctional reagents for quantitative proteome-wide analysis of protein modification in human cells and dynamic profiling of protein lipidation during vertebrate development. Angew. Chem. Int. Ed. Engl. 54, 5948-51.

(2) Parker, C. G., Galmozzi, A., Wang, Y., Correia, B. E., Sasaki, K., Joslyn, C. M., Kim, A. S., Cavallaro, C. L., Lawrence, R. M., Johnson, S. R., Narvaiza, I., Saez, E., and Cravatt, B. F. (2017) Ligand and Target Discovery by Fragment-Based Screening in Human Cells. Cell 168, 527-541.e29.

(3) Wang, Z., Grosskurth, S. E., Cheung, T., Petteruti, P., Zhang, J., Wang, X., Wang, W., Gharahdaghi, F., Wu, J., Su, N., Howard, R. T., Mayo, M., Widzowski, D., Scott, D. A., Johannes, J. W., Lamb, M. L., Lawson, D., Dry, J. R., Lyne, P. D., Tate, E. W., Zinda, M., Mikule, K., Fawell, S. E., Reimer, C., and Chen, H. (2018) Pharmacological Inhibition of PARP6 Triggers Multipolar Spindle Formation and Elicits Therapeutic Effects in Breast Cancer. Cancer Res. 78, 6691-6702.

(4) Hutin, D., Grimaldi, G., and Matthews, J. (2018) Methods to Study TCDD-Inducible PolyADP-Ribose Polymerase (TIPARP) Mono-ADP-Ribosyltransferase Activity, in ADPribosylation and NAD+ Utilising Enzymes, pp 109-124. Humana, New York, NY. 


\section{NMR Spectra}

Tert-butyl 4-(3-cyanopyridin-2-yl)piperazine-1-carboxylate 2

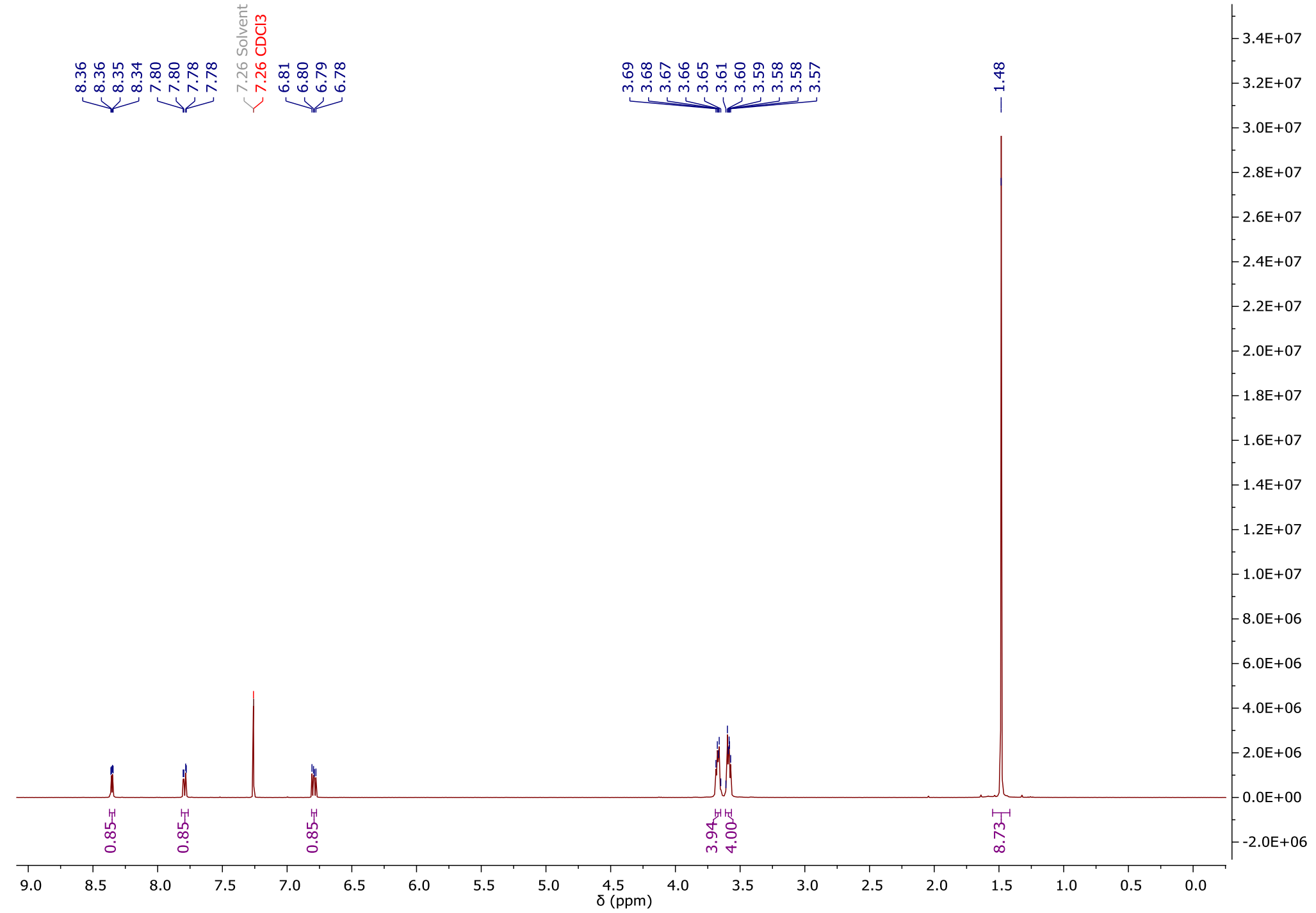


Tert-butyl 4-(5-bromo-3-cyanopyridin-2-yl)piperazine-1-carboxylate 3

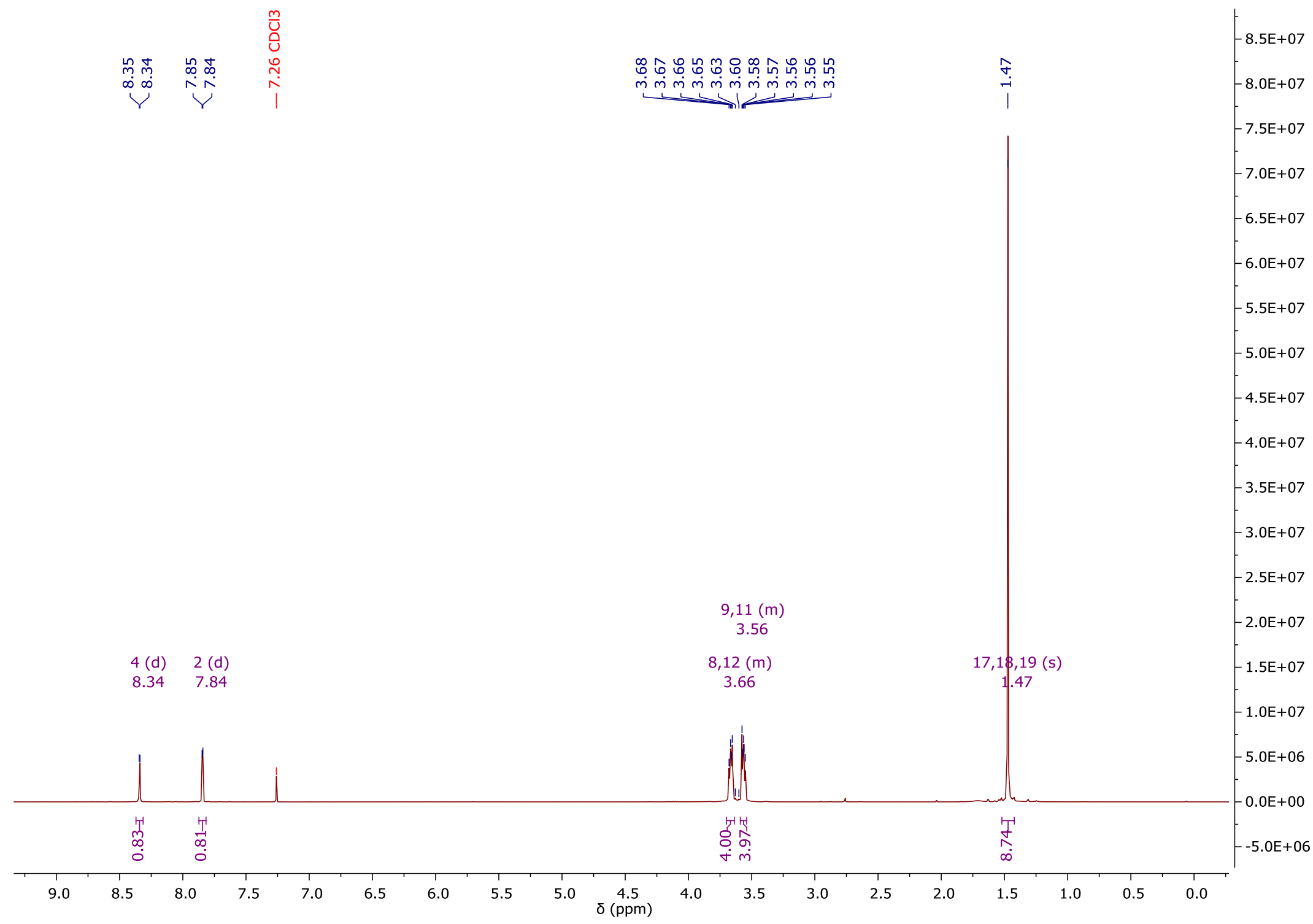


Tert-butyl 4-(5-amino-3-cyanopyridin-2-yl)piperazine-1-carboxylate 4

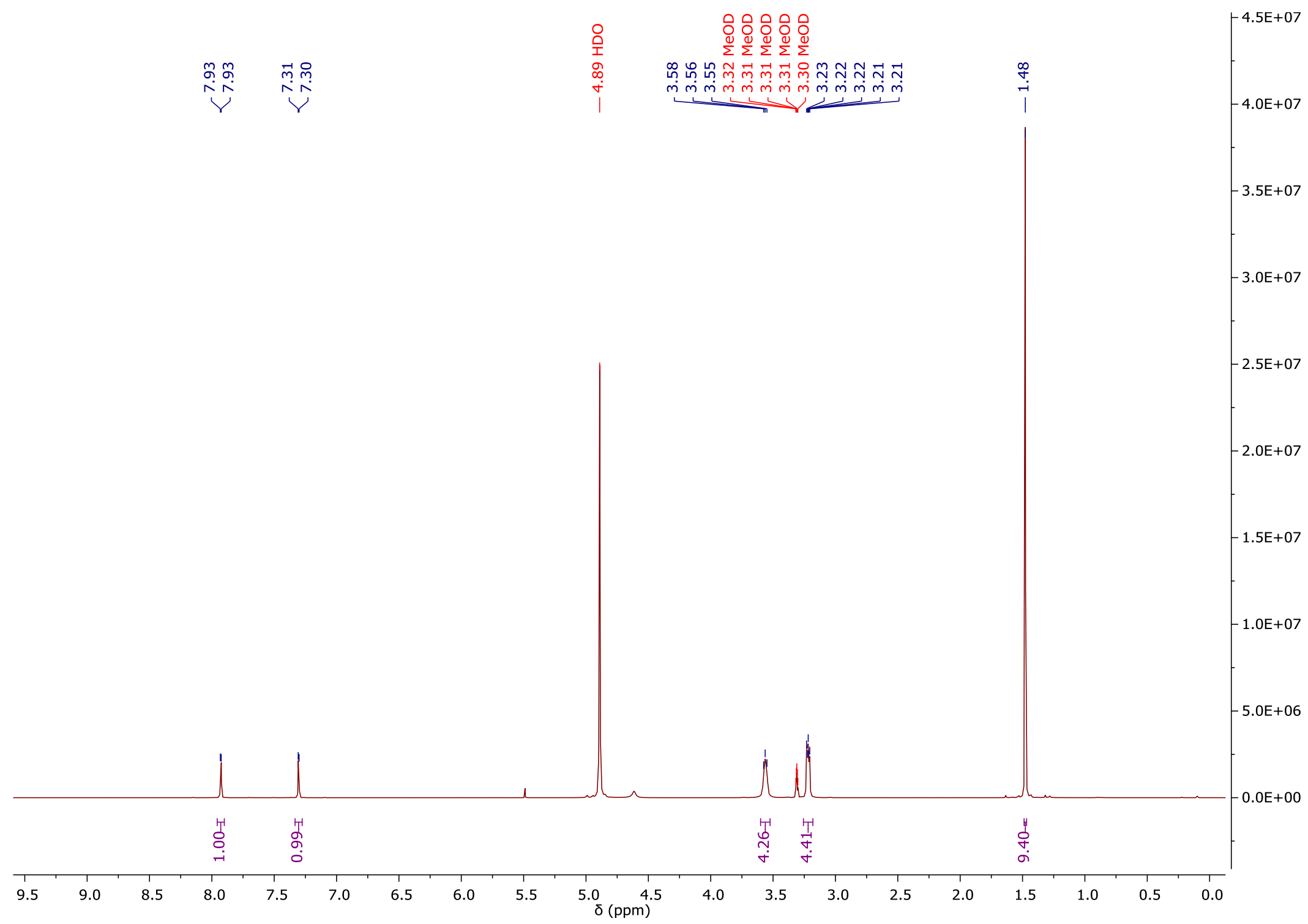


Tert-butyl 4-(5-(3-(3-(but-3-yn-1-yl)-3H-diazirin-3-yl)propanamido)-3-cyanopyridin-2-yl)piperazine-1-carboxylate 6

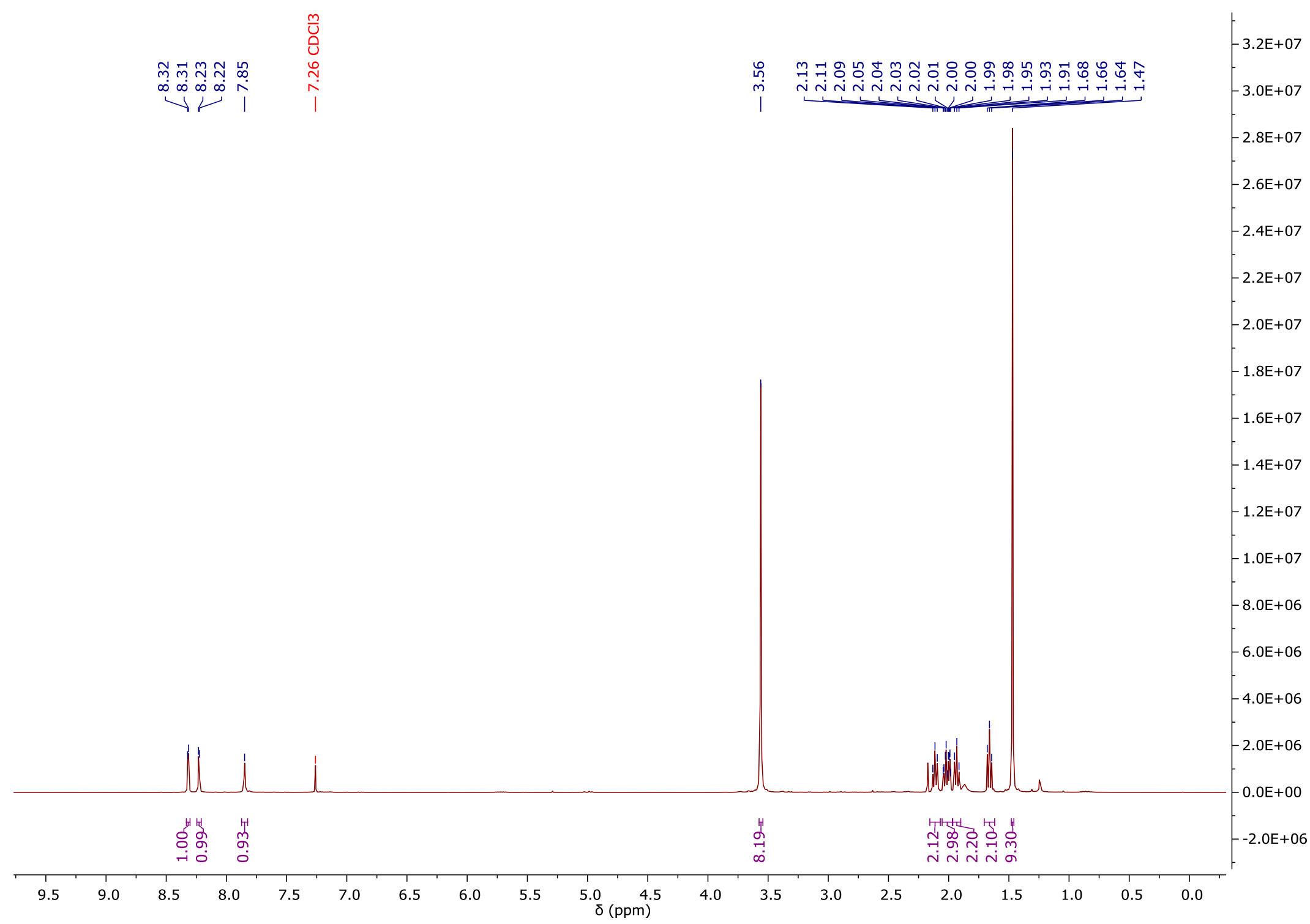




\section{3-(3-(But-3-yn-1-yl)-3H-diazirin-3-yl)-N-(5-cyano-6-(piperazin-1-yl)pyridin-3-yl)propanamide 7}




3-(3-(But-3-yn-1-yl)-3H-diazirin-3-yl)-N-(5-cyano-6-(4-(3-((4-oxo-3,4-dihydrophthalazin-1-yl)methyl)benzoyl)piperazin-1-yl)pyridin-3yl)propanamide (PARPYnD)

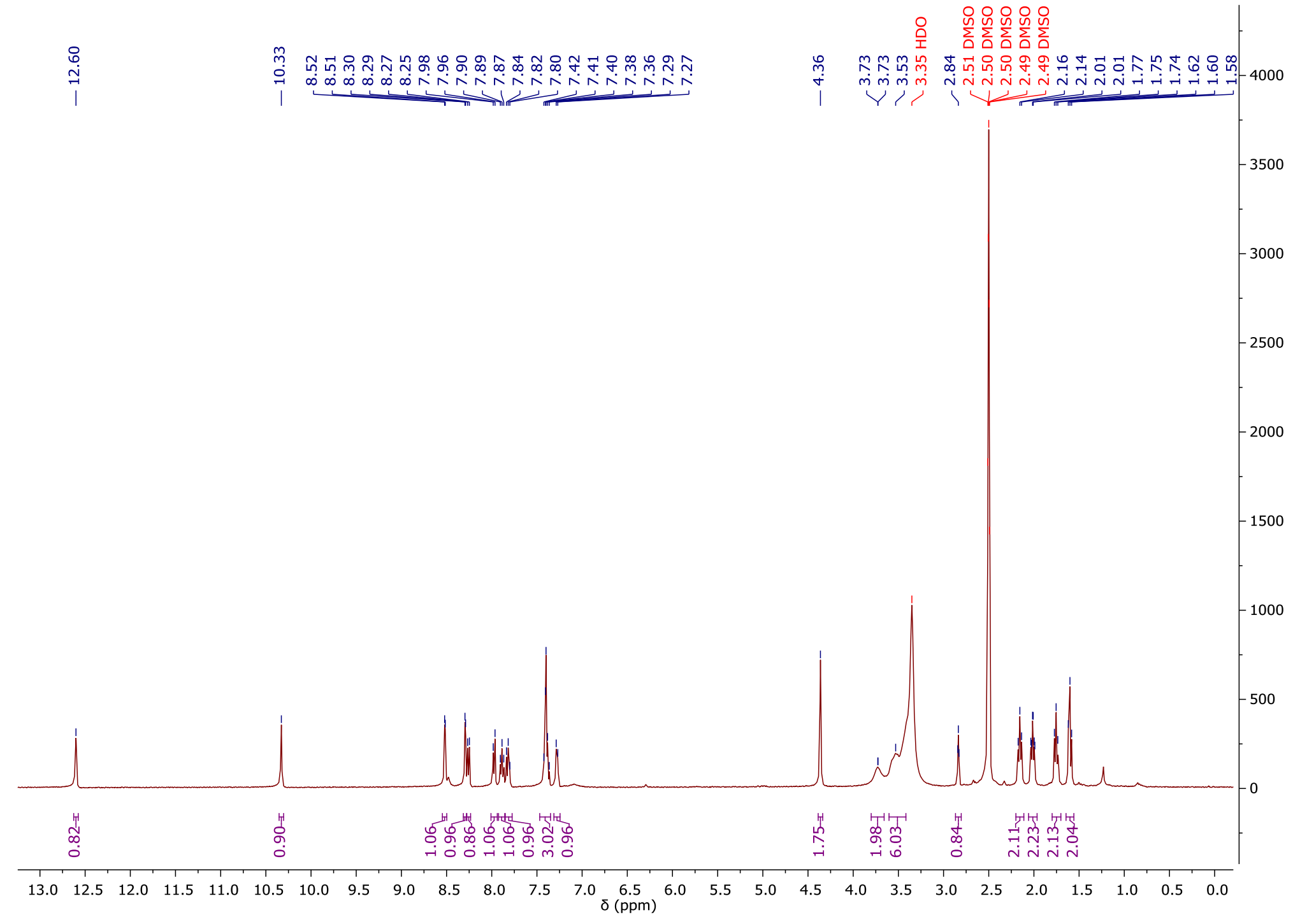

